\title{
Anthropogenic chlorofluorocarbons in the Black Sea and the Sea of Marmara
}

\author{
Bing-Sun Lee ${ }^{\mathrm{a}}$, John L. Bullister ${ }^{\mathrm{b}, *}$, James W. Murray ${ }^{\mathrm{c}}$, Rolf E. Sonnerup ${ }^{\mathrm{d}}$ \\ ${ }^{a}$ National Center for Ocean Research, P.O. Box 23-13, Taipei, Taiwan 10617, ROC \\ ${ }^{\mathrm{b}}$ National Oceanic and Atmospheric Administration, Pacific Marine Environmental Laboratory, 7600 Sand Point Way NE, \\ Seattle, WA 98115 0070, USA \\ ${ }^{\mathrm{c}}$ School of Oceanography, University of Washington, Box 357940, Seattle, WA 98195-7940, USA \\ ${ }^{\mathrm{d}}$ Joint Institute for the Study of Oceans and Atmospheres, University of Washington, Box 354235, Seattle, WA 98195-4235, USA
}

Received 29 June 2001; accepted 10 December 2001

\begin{abstract}
Measurements of the distributions of two chlorofluorocarbons, $\mathrm{CCl}_{3} \mathrm{~F}(\mathrm{CFC}-11)$ and $\mathrm{CCl}_{2} \mathrm{~F}_{2}(\mathrm{CFC}-12)$, made during the June/July 1988 R. V. Knorr cruise in the Black Sea indicate that CFC-11 is non-conservative relative to CFC-12 in the strongly reducing anoxic waters. A multi-layer model combining horizontal/vertical renewal and vertical diffusion processes was tuned to the distributions of CFC-12 and salinity in suboxic and anoxic waters and used to estimate the residence times of subsurface waters and first-order in situ removal rate constants for CFC-11. The model-calculated residence times were $\sim 5 \mathrm{yr}$ in the suboxic zone $(80-120 \mathrm{~m})$ and increased to $\sim 625 \mathrm{yr}$ at $500 \mathrm{~m}$. The first-order CFC-11 in situ removal coefficients were $0.52 \pm 0.19 \mathrm{yr}^{-1}$ for the depth range $160-480 \mathrm{~m}$. Based on the observed CFC-12 concentrations, the residence time of cold intermediate layer water $(\sim 50-100 \mathrm{~m})$ was estimated to be $<5 \mathrm{yr}$. The residence time of the deep water (100-450 m) in the Sea of Marmara was estimated to be 12-19 yr using a box model tuned to CFC-12, implying an in situ oxygen utilization rate of $10-18 \mu \mathrm{mol} \mathrm{kg}^{-1} \mathrm{yr}^{-1}$. (C) 2002 Elsevier Science Ltd. All rights reserved.
\end{abstract}

Keywords: Anoxia; Chlorofluorocarbons; Mathematical models; Residence time; Tracers; Black Sea

\section{Introduction}

The Black Sea (Fig. 1) is the world's largest anoxic basin. A low salinity upper layer, maintained by freshwater inputs from many rivers

\footnotetext{
*Corresponding author. Tel.: +1-206-526-6741; fax: +1206-526-6744.

E-mail addresses: blee@odb03.ncor.ntu.edu.tw (B.-S. Lee), bullister@pmel.noaa.gov (J.L. Bullister),jmurray@u.washington.edu (J.W. Murray), sonnerup@pmel.noaa.gov (R.E. Sonnerup).
}

(Fig. 1), overlays a more saline layer which is maintained by Mediterranean waters supplied to the Black Sea through the Bosporus Strait. The saline inflow mixes with a sub-surface "cold intermediate water" layer (CIL) to ventilate the deep basin (Murray et al., 1991; Buesseler et al., 1991). The sinking of organic material from the surface and subsequent remineralization at depth, combined with the strong stratification of the water column and slow renewal times for deep waters, leads to anoxic conditions at depths $>\sim 100 \mathrm{~m}$. 


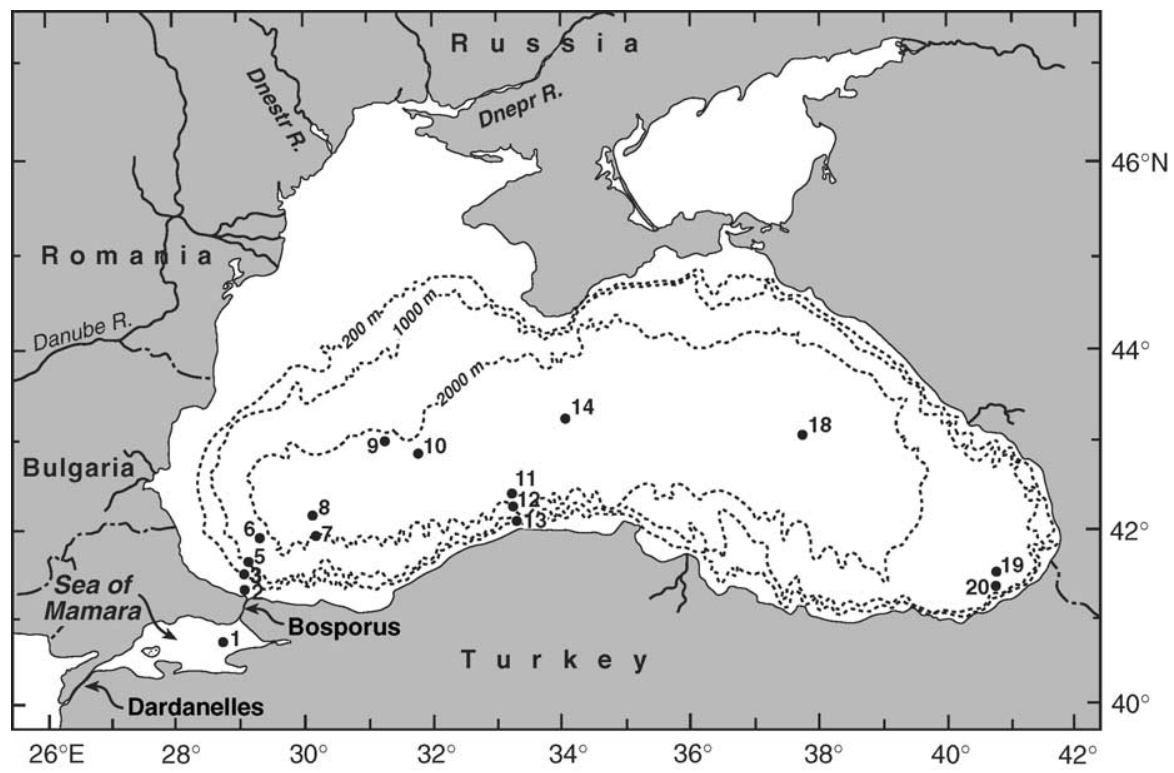

Fig. 1. Location of stations on Leg 4 of the 21 June-4 July 1988 Black Sea expedition.

Ventilation rates for deep waters in the Black Sea are poorly known. An estimate of the residence time of deep water based on ${ }^{14} \mathrm{C}$ was $2000 \mathrm{yr}$ (Östlund and Dyrssen, 1986), while a budget of heat and salt indicated a turnover time of $\sim 387 \mathrm{yr}$ (Murray et al., 1991). Because these turnover times are useful for constraining rates of the geochemical processes occurring in the Black Sea, chlorofluorocarbons were analyzed during a 1988 US-Turkish expedition to further constrain the rate of this ventilation process.

The chlorofluorocarbons (CFCs), $\mathrm{CFC}-12$ $\left(\mathrm{CCl}_{2} \mathrm{~F}_{2}\right)$ and $\mathrm{CFC}-11\left(\mathrm{CCl}_{3} \mathrm{~F}\right)$ are entirely anthropogenic compounds whose production and atmospheric release began in the 1930s. Due to the rapid rise in production and the stability of these gases in the troposphere, CFC levels in the atmosphere increased dramatically during the following decades. Photocatalytic reactions with ozone in the stratosphere provide the major sink for CFCs, whose atmospheric lifetimes are 180 and $44 \mathrm{yr}$ for CFC-12 and CFC-11, respectively (Cunnold et al., 1994). Atmospheric CFC levels have been monitored globally since $\sim 1978$. A reconstruction of the CFC atmospheric history for the period 1930-1978 can be made based on estimates of production and release of CFCs and their atmospheric lifetimes, normalized to atmospheric CFC measurements made since 1978. In this study, reconstructed histories of the concentrations of CFC-11 and CFC-12 in the atmosphere (Walker et al., 2000) were normalized to atmospheric measurements made during the Black Sea expedition in 1988 (Fig. 2).

Dissolved CFC-12 and CFC-11 are widely employed as transient tracers for water dating and ocean mixing and circulation studies (e.g. Gammon et al., 1982; Bullister and Weiss, 1983; Weiss et al., 1985; Doney and Bullister, 1992). CFCs have also been used to estimate oxygen utilization rates (OURs) (Doney and Bullister, 1992; Warner et al., 1996) and anthropogenic $\mathrm{CO}_{2}$ uptake by the oceans (Gammon et al., 1982; Matear and Wong, 1997; Sabine et al., 1999). Most CFC applications have assumed that there are no in situ sources or sinks of CFCs in the ocean. However, in some marine environments, the use of CFCs as tracers may be complicated by the fact that CFC removal has been reported under anaerobic conditions in soils (Khalil and 


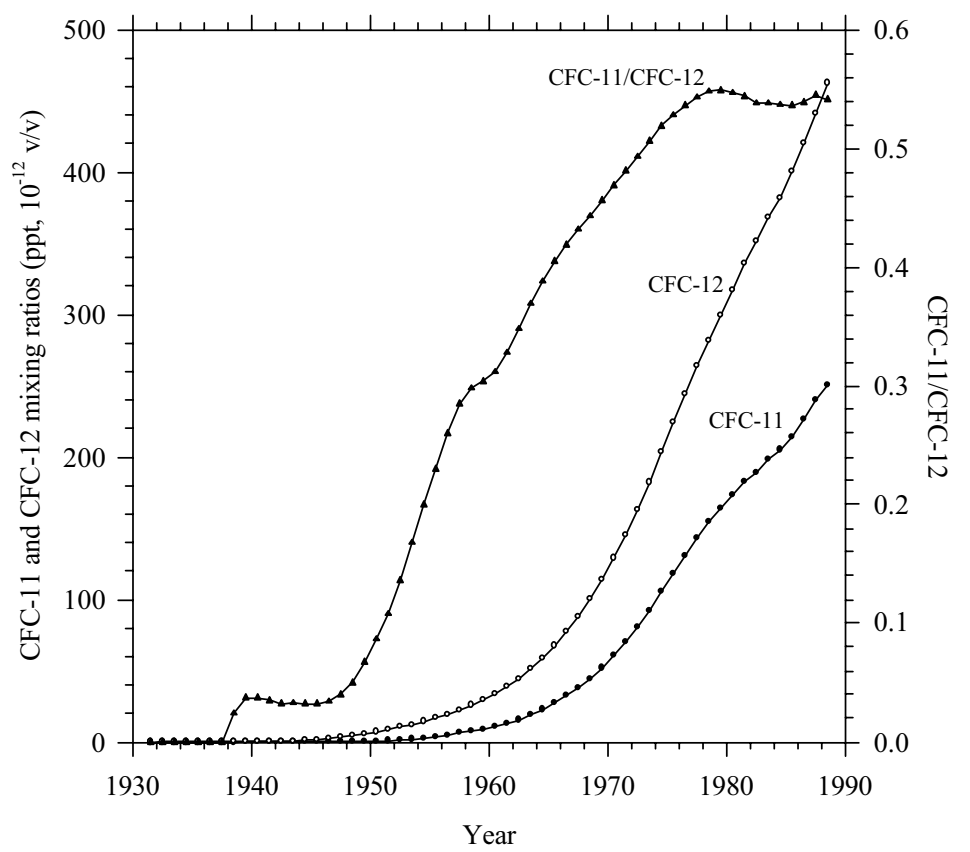

Fig. 2. Reconstructed history of atmospheric CFC-11 and CFC-12 concentration (dry air mole fraction in parts-per-trillion) in the Northern Hemisphere, normalized to 1988 air measurements in the Black Sea.

Rasmussen, 1989), rice fields (Khalil et al., 1990) and organic-rich freshwater sediments (Lovley and Woodward, 1992). In seawater, CFC-11 consumption in strongly reducing (anoxic) marine environments like Saanich Inlet (Bullister and Lee, 1995; Lee et al., 1999) and Framvaren Fjord (Shapiro et al., 1997) has been reported, but CFC-12 appears to be conservative in these environments.

In this paper we use CFC measurements collected during a 1988 US-Turkish expedition in the Black Sea (Murray, 1991a,b) to calculate water exchange and $\mathrm{CFC}-11$ removal rates in suboxic and anoxic waters. Assuming that CFC-12 is a conservative tracer, a simple mixing model is tuned to the 1988 CFC-12 inventories observed in the Black Sea. The model is used to estimate deep water residence times and CFC-11 removal rates in the Black Sea's suboxic and anoxic waters. Finally, we use a simple mixing model and CFC observations from the adjacent Sea of Marmara to estimate the residence time and OUR of deep waters there.

\section{Hydrographic background}

\subsection{The Black Sea}

Black Sea waters can be classified as oxygenated surface waters, suboxic waters, and anoxic (hydrogen sulfide-bearing) waters. Large chemical gradients are present in the water column extending from the surface into the suboxic and anoxic zones (Codispoti et al., 1991). Isopycnal surfaces above $300 \mathrm{~m}$ are dome-shaped, that is, shallower in the central parts of the Black Sea reflecting the cyclonic circulation (Caspers, 1957). The oxygenated surface layer ranges in thickness from $\sim 50 \mathrm{~m}$ in the central basin to $\sim 150 \mathrm{~m}$ near the margins. Immediately below the surface layer is the cold intermediate layer (CIL) where temperature decreases to a minimum. The upper and lower boundaries of the CIL $\left(\sigma_{\theta}=14.29-15.45\right)$ are defined by the depths of the $8^{\circ} \mathrm{C}$ isotherms (Murray et al., 1991) above and below the temperature minimum. Two mechanisms have 
been proposed for the formation of CIL water. First, CIL water has been reported to originate in the Northwestern Shelf (NWS) region of the Black Sea (Neumann, 1943; Filippov, 1968; Tolmazin, 1985; Sanchez et al., 1991). In this region, a combination of cold temperatures and low river run-off during wintertime forms dense slope water which descends and spreads laterally across the Black Sea (Georgiev, 1967; Filippov, 1968; Boguslavsky et al., 1976; Blatov et al., 1980). Second, Ovchinnikov and Popov (1987) discuss the possibility that CIL water is formed in the centers of the cyclonic gyres, and subsequently spirals outward along the dome-shaped isopycnal surfaces. Ivanov et al. (1997) concluded that both sources are important and noted that the two reservoirs of CIL are separated by a rim current in the Black Sea.

The oxic-anoxic interface $\left(\sigma_{\theta}=15.45-16.16\right)$ below the CIL has been characterized as a "suboxic zone" (Murray et al., 1995). In the central basin, oxygen decreases from $\sim 10 \mu \mathrm{M}$ at $\sigma_{\theta}=15.45(\sim 80 \mathrm{~m})$ to $<2 \mu \mathrm{M}$ at $\sigma_{\theta}=16.16$ $(\sim 115 \mathrm{~m})$. There do not appear to be any discernible horizontal $\mathrm{O}_{2}$ gradients on isopycnal surfaces in this density range (Luther et al., 1991). In the suboxic zone hydrogen sulfide concentrations are $<5 \mathrm{nM}$. Beneath the suboxic zone, waters are strongly reducing and devoid of oxygen and nitrate, and hydrogen sulfide and silicate increase with depth at densities $>\sigma_{\theta}=16.16$ (Luther et al., 1991; Murray et al., 1995).

Residence times of Black Sea deep waters have been estimated using different tracers and methods. Murray et al. (1991) used salinity, heat and mass budgets to calculate a mean residence time of the Black Sea deep water (below $50 \mathrm{~m}$ ) of $\sim 387 \mathrm{yr}$ and estimated that the ratio of entrainment of near-surface Black Sea water with Bosporus inflow waters was $\sim 3.3: 1$. Hydrographic relationships suggested that the water being entrained is from the CIL (Murray et al., 1991; Özsoy et al., 1993). Top et al. (1990) used a calculated ${ }^{4} \mathrm{He}$ sediment flux and water column ${ }^{4} \mathrm{He}$ analysis to estimate an upper limit for the residence time of the Black Sea deep water of $850 \pm 300 \mathrm{yr} .{ }^{14} \mathrm{C}$ data, on the other hand, yielded an estimate of about $2000 \mathrm{yr}$ (Östlund and Dyrssen, 1986).

\subsection{The Sea of Marmara}

The Sea of Marmara is connected to the Mediterranean Sea via the Dardanelles and to the Black Sea via Bosporus Strait (Fig. 1). Relatively, low salinity, low density water from the Black Sea flows into the Sea of Marmara via the Bosporus while relatively high salinity, dense Mediterranean water enters the Sea of Marmara via the Dardanelles. As a result the water column of the Sea of Marmara has a two layer structure with a strong halocline at about $25 \mathrm{~m}$. Because of its relatively small size, the renewal time of deep waters in the Sea of Marmara by surface water is much faster than in the Black Sea $(\sim 6-7 \mathrm{yr}$, Besiktepe et al., 1993) such that deep water in the Sea of Marmara is oxygenated.

\section{Measurement methods}

Concentrations of CFC-11 and CFC-12 in seawater and air were measured during the June 21-July 4, 1988 cruise by shipboard electroncapture gas chromatography (Bullister and Weiss, 1988). Water samples for CFC analysis were collected using 301 Niskin bottles mounted on a rosette frame. Individual samples were carefully isolated in $100 \mathrm{ml}$ ground glass syringes to avoid contamination with shipboard air. Water samples were analyzed by injecting $\sim 30 \mathrm{~cm}^{3}$ into a glass stripping chamber fitted with a sintered glass frit. CFC-free carrier gas, (5\% methane in argon), was bubbled through the water to purge CFCs from the sample. A column of Ascarite ${ }^{\mathbb{R}}$ was placed downstream of a magnesium perchlorate drying tube to remove hydrogen sulfide. The purgestream CFCs were collected and concentrated on a Porasil $\mathrm{C} /$ Porapak $\mathrm{T}$ trap at $-30^{\circ} \mathrm{C}$. The trap was then heated to $100^{\circ} \mathrm{C}$ to transfer the $\mathrm{CFCs}$ from the extraction system to a gas chromatograph. CFCs were first separated from more slowly eluting compounds on a $\sim 25 \mathrm{~cm}$ Porasil C precolumn. Final separation was on a $\sim 90 \mathrm{~cm}$ Porasil C column. CFCs were detected using a constant-current ${ }^{63} \mathrm{Ni}$ electron capture detector. Peak areas were determined by digital integration, and the non-linear response of the detector was 
calibrated by injecting known amounts of a standard gas. CFC concentrations are reported as parts per trillion (mole fraction of CFC in dry air) for air samples, and in picomoles (pmol or $10^{-12}$ moles) per kilogram (pM) for water samples. All samples are referenced to the SIO-1998 calibration scale (Walker et al., 2000; Prinn et al., 2000), which is based on primary standards prepared in the laboratory by volumetric dilution. The estimated accuracy of this calibration scale is $\sim 1 \%$ for CFC-11 and CFC-12 (Prinn et al., 2000). The precision of the seawater measurements, as given by the mean standard deviation for replicate samples, was $\sim 0.01 \mathrm{pmol} / \mathrm{kg}$ or $1 \%$ (whichever is greater) for both CFC-11 and CFC-12, and systematic sampling and handling errors were estimated to be of the same order.

Measured volumes of clean ambient air $(\sim 3 \mathrm{cc})$, drawn from a continuously pumped sampling line at the bow were dried with magnesium perchlorate and analyzed by injection into the same lowtemperature trapping system. The relative standard deviation of the atmospheric measurements, based on replicate analyses, was $\sim 1 \%$ for CFC- 11 and $\sim 0.4 \%$ for CFC-12. Overall systematic calibration errors were estimated to be $\sim 2 \%$ for both gases.

\section{Results}

Hydrographic and CFC data were obtained at $\sim 20$ stations (Fig. 1) on Leg 4 of the 1988 Black Sea oceanographic expedition during June 1988 on R.V. Knorr. CFC-11 and CFC-12 concentrations were highest in the near-surface waters, but were detectable well into the suboxic and anoxic layers (Fig. 3). CFC concentrations were near or below the detection limit at depths $>500 \mathrm{~m}$. Summertime CFC-11 and CFC-12 saturation levels in nearsurface waters were as high as $\sim 160 \%$ and $\sim 150 \%$, respectively (Fig. 4), based on the average of all atmospheric measurements $(264.6 \pm 3.2$ and $493.4 \pm 6.7 \mathrm{ppt}$ for $\mathrm{CFC}-11$ and $\mathrm{CFC}-12$, respectively) during the cruise. In near-surface waters dissolved oxygen reached saturation levels of $125 \%$. The extreme supersaturations for dissolved CFCs in the near-surface water may be due
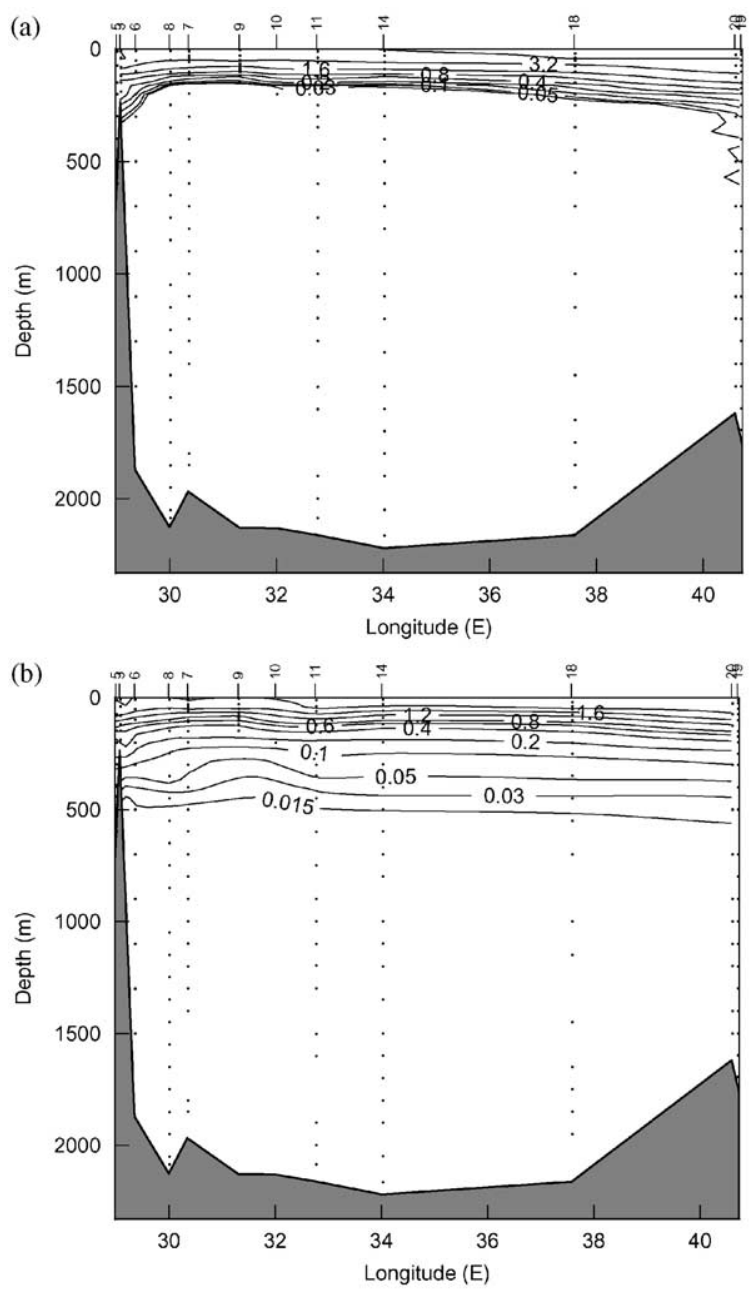

Fig. 3. Vertical CFC-11 (a) and CFC-12 (b) sections across the Black Sea during the 1988 Black Sea expedition. Station numbers are listed at the top of the figure. All dissolved CFC concentrations are expressed as $\mathrm{pmol} \mathrm{kg}^{-1}$ (1 pmol $\mathrm{kg}^{-1}=10^{-12} \mathrm{~mol} \mathrm{~kg}^{-1}$ of seawater). The gridding and contouring were done using an optimal estimation technique developed by Roemmich (1983).

to (1) sample contamination; (2) periodic episodes of elevated levels of atmospheric CFCs over this region; (3) rapid seasonal warming of near-surface waters combined with relatively slow rates of airsea gas exchange.

The fact that the CFC-11 and CFC-12 supersaturations were within $\sim 10 \%$ of each other argues against contamination from shipboard or Niskin bottle sources, since these usually affect one 


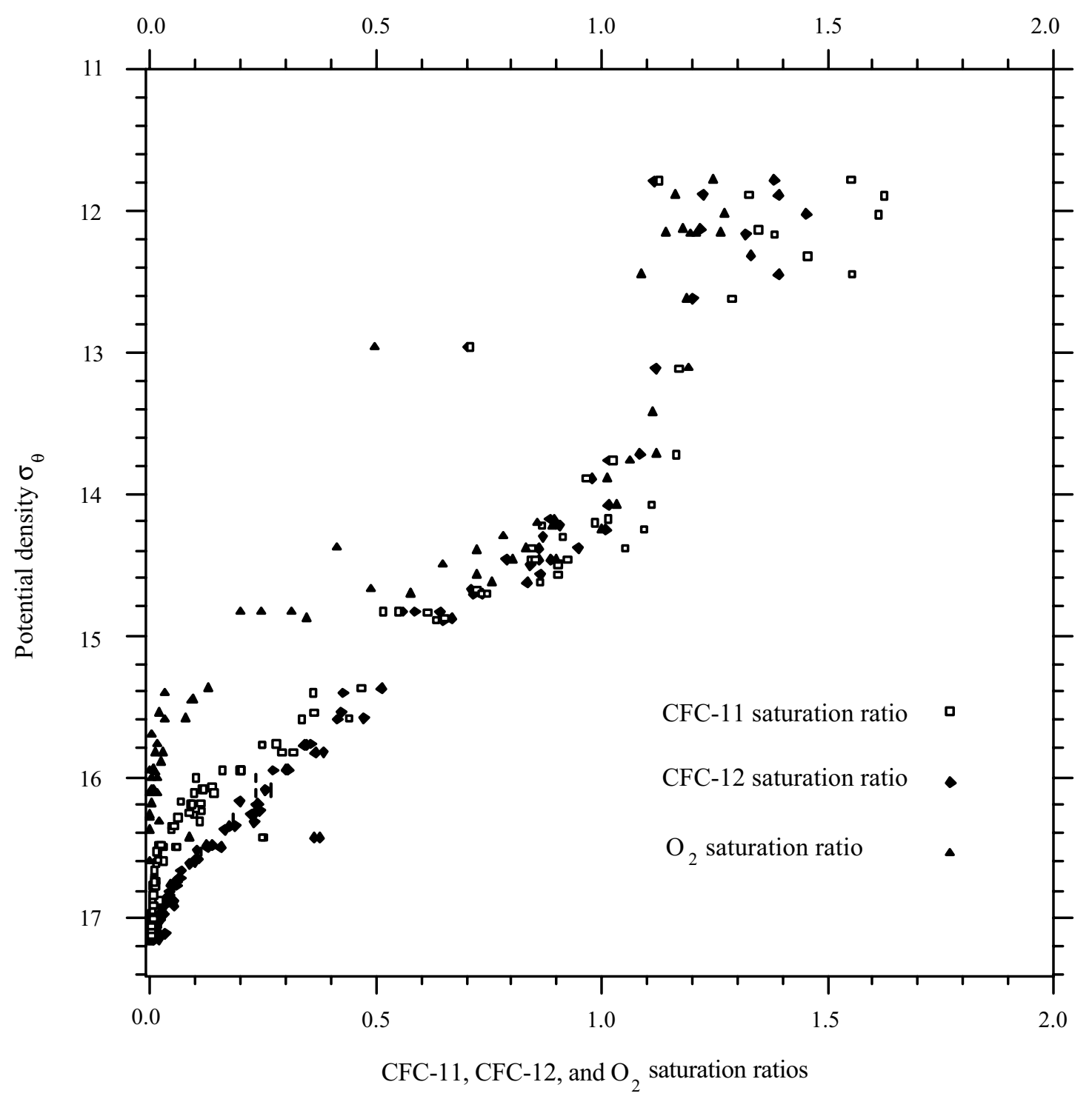

Fig. 4. CFC-12, CFC-11, and dissolved $\mathrm{O}_{2}$ saturations versus potential density $\left(\sigma_{\theta}\right)$ for all CFC stations in the Black Sea. The elevated levels at $\sigma_{\theta} \sim 16.4$ are from the near bottom maxima at station 3, near the Bosporus outflow.

CFC much more strongly than the other. No evidence for severe contamination of CFC-11 or CFC-12 was seen in the deep samples collected at these stations. CFC sample contamination at levels $\left(\sim 1 \mathrm{pmol} \mathrm{kg}^{-1}\right)$ needed to bring the surface saturations to $>150 \%$ would be obvious if it occurred in deep water samples. A prolonged period of elevated levels of atmospheric CFCs over the Black Sea occurring a month or more before the cruise could drive near-surface dissolved CFC concentrations to high levels, which would then persist for weeks even after the atmospheric CFC levels returned to background levels. No CFC air measurements over the Black Sea are available for the period immediately preceding Leg 4 , so this possibility cannot be eliminated. However, the 
Fig. 5. Vertical profiles of potential temperature $(\theta)$, salinity, dissolved $\mathrm{O}_{2}$ and $\sigma_{\theta}$ (a) and vertical profiles of CFC-11, CFC-12 and dissolved $\mathrm{O}_{2}$ (b) at station $3\left(41^{\circ} 34^{\prime} \mathrm{N} 29^{\circ} 04^{\prime} \mathrm{E}\right)$ near the Bosporus outflow into the Black Sea.

average of daily air measurements of CFCs made on Leg 4 were only slightly $(6-7 \%)$ above clean Northern Hemisphere background values (Walker et al., 2000) for this time period, and varied by $<2 \%$ from 21 June to 4 July 1988.

The most likely cause of the observed summertime CFC supersaturations is rapid surface warming by solar radiation (e.g. Murray et al., 1991), combined with slow gas exchange in the highly stratified near-surface layer of the Black Sea. Rapid cooling of the near-surface layer in winter produces a mixed layer with temperatures of $\sim 8^{\circ} \mathrm{C}$ down to the depth of the CIL $\left(\sigma_{\theta}=14.46\right)$ (Tolmazin, 1985; Ovchinnikov and Popov, 1987; Sanchez et al., 1991). CFC gas exchange rates are relatively rapid in winter, due to the low stratification and high mean wind speeds (Tolmazin, 1985). The solubilities of CFC-11 and CFC-12 decrease by $\sim 4 \%$ per ${ }^{\circ} \mathrm{C}$ temperature increase (Warner and Weiss, 1985). If the CFC concentrations in nearsurface water in wintertime are assumed to be near equilibrium at wintertime temperatures $\left(\sim 8^{\circ} \mathrm{C}\right)$, then an increase in temperature from $8^{\circ} \mathrm{C}$ to $23^{\circ} \mathrm{C}$ (in the absence of gas exchange) could lead to CFC summertime saturation levels of $>200 \%$. Thus, the $\sim 150 \%$ CFC supersaturation levels observed in the summer of 1988 are probably the result of seasonal warming combined with the substantially lower mean wind speeds in spring and summer (Woodruff et al., 1998) allowing only partial reequilibration of the upper water during the warming.

Depth profiles of potential temperature, salinity, dissolved oxygen $\left(\mathrm{O}_{2}\right)$, CFC-11 and CFC-12 from the Black Sea at station 3, near the exit of Bosporus Strait, are shown in Fig. 5. Subsurface maxima in both CFCs and dissolved oxygen were observed at $190 \mathrm{~m}$. These maxima suggest that the inflowing plume containing entrained near surface origin water penetrates to this depth, carrying with it elevated levels of CFCs and dissolved oxygen.

Profiles of dissolved $\mathrm{O}_{2}$, nitrate $\left(\mathrm{NO}_{3}^{-}\right), \mathrm{H}_{2} \mathrm{~S}$, potential temperature $(\theta)$, salinity and potential (a) $\mathrm{O}_{2}(\mu \mathrm{mol} / \mathrm{kg})$
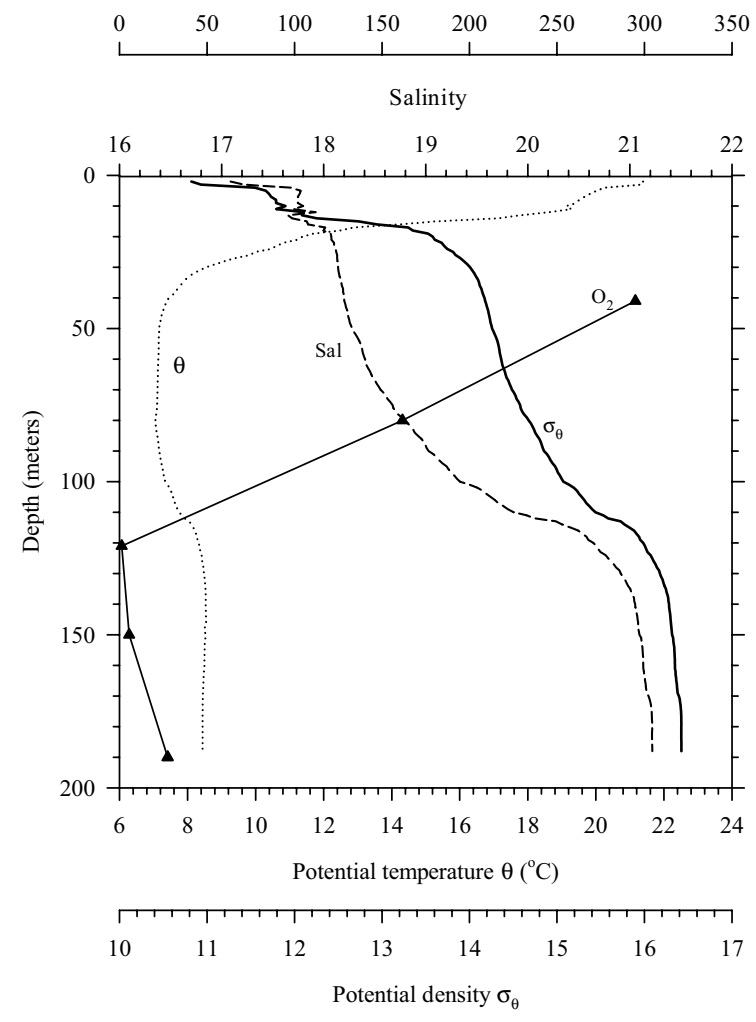

(b)

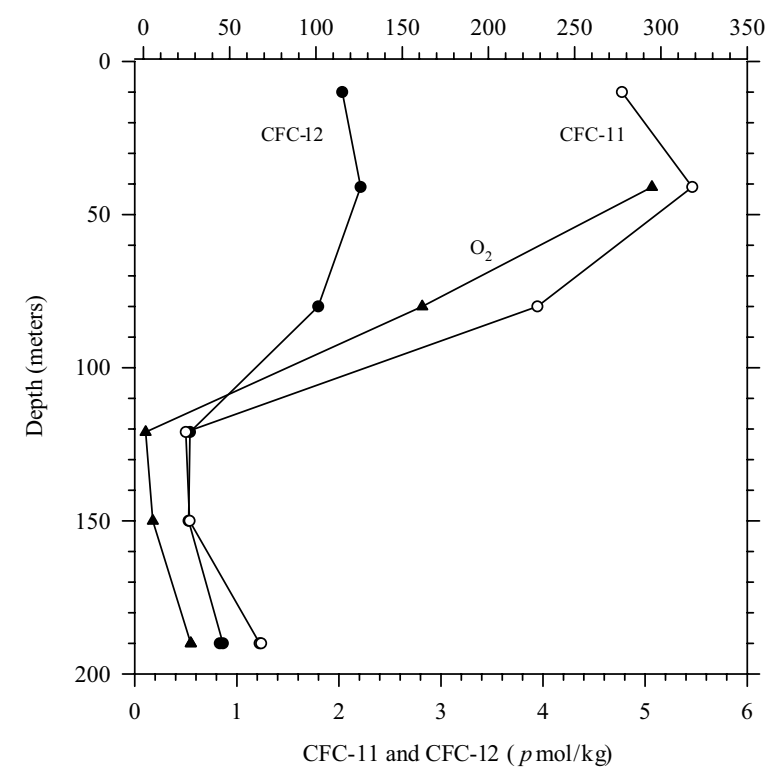


Fig. 6. Vertical profiles of $\theta$, salinity, $\sigma_{\theta}$, dissolved $\mathrm{O}_{2}, \mathrm{H}_{2} \mathrm{~S}$ and $\mathrm{NO}_{3}$ (a) and vertical profiles of dissolved CFC-11 and CFC-12 (b) at the location of station $14\left(43^{\circ} 05^{\prime} \mathrm{N} \quad 34^{\circ} 00^{\prime} \mathrm{E}\right)$, a representative station near the center of the Black Sea (White et al., 1989). Continuous measurements of $\mathrm{NO}_{3}^{-}$and $\mathrm{H}_{2} \mathrm{~S}$ were made using a lowered pump profiling system (Friederich et al., 1990). Also shown is the CFC-11/CFC-12 ratio for samples where the CFC-11 and CFC-12 concentrations were both $>0.05 \mathrm{pmol} \mathrm{kg}^{-1}$.

density $\left(\sigma_{\theta}\right)$ at station 14 , a typical station near the center of the Black Sea, are shown in Fig. 6a. Profiles of dissolved CFC-11, CFC-12 and the CFC-11/CFC-12 ratio are shown in Fig. 6b. As predicted from the overlying atmospheric CFC concentrations and their solubilities, the dissolved CFC-11 concentrations were higher than CFC-12 in oxygenated waters. However, this trend was reversed at depth $(>\sim 100 \mathrm{~m})$ at this station. Composite profiles of potential density versus dissolved CFCs and $\mathrm{O}_{2}$ saturation ratios from all stations sampled in the Black Sea (Fig. 4) illustrate that CFC-11 saturations are lower than those of CFC-12 starting near the upper boundary of the suboxic layer $\left(\sigma_{\theta}=15.45\right)$ and the CFC-11 depletion signal is more prominent with increasing density in the anoxic water, suggesting strong CFC-11 removal at depth.

Vertical distributions of salinity, potential temperature, potential density, CFC-12, CFC-11 and dissolved $\mathrm{O}_{2}$ at station 1 in the Sea of Marmara are shown in Fig. 7a and b. Low salinity water of Black Sea origin extends from the surface to $\sim 20$ $25 \mathrm{~m}$. The remainder of the water column (below $25 \mathrm{~m})$ is high salinity $(\sim 38.5)$ Aegean Sea water. Dissolved $\mathrm{O}_{2}$ was present throughout the water column and $\mathrm{H}_{2} \mathrm{~S}$ was below detection. CFC-11 and CFC-12 concentrations were $>0.5 \mathrm{pmol} \mathrm{kg}^{-1}$ in all samples (Fig. 7b) and in contrast to the Black Sea, the concentration of CFC-11 was higher than that of $\mathrm{CFC}-12$ in all samples in the water column at this station.

\section{Inferring turnover times from CFC data}

\subsection{CFC-12 dating of CIL waters}

An estimate of the ventilation timescale for CIL can be made based on the saturation levels for (a)
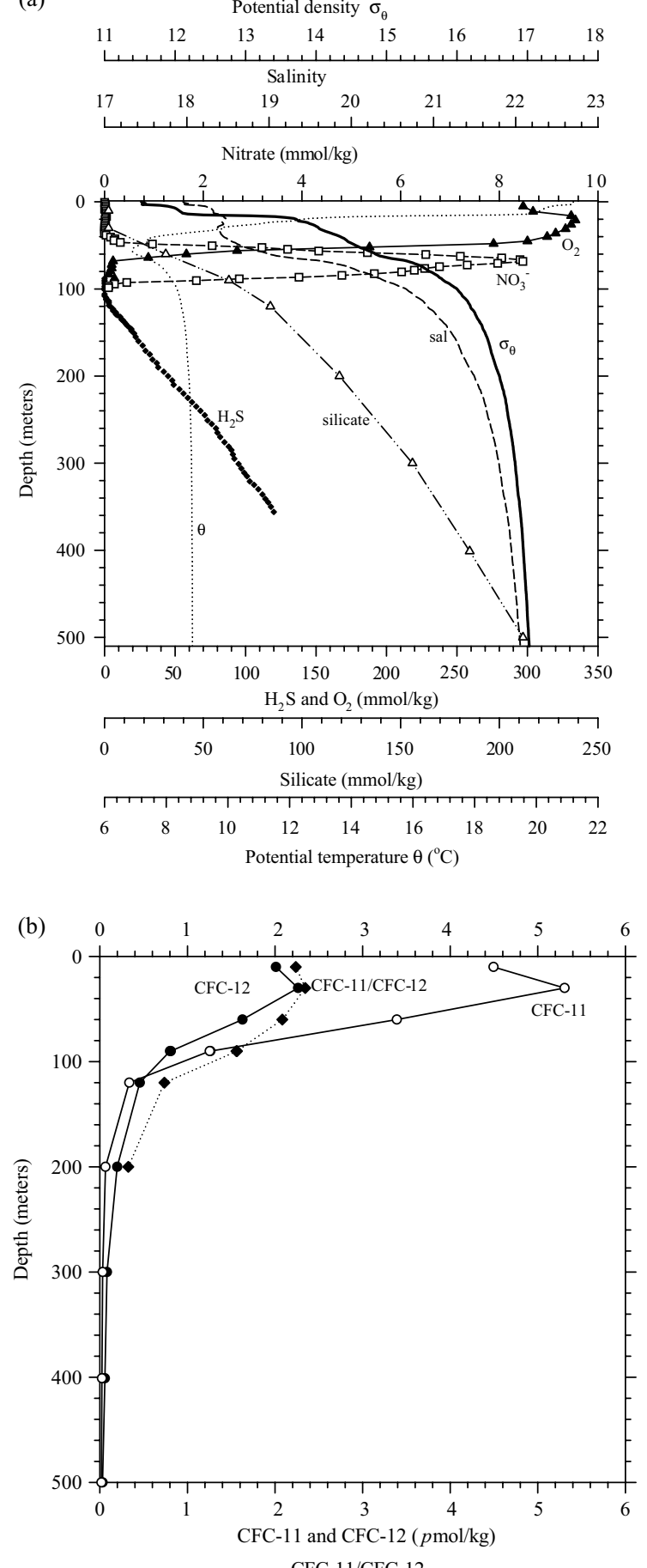

CFC-11/CFC-12 
(a)

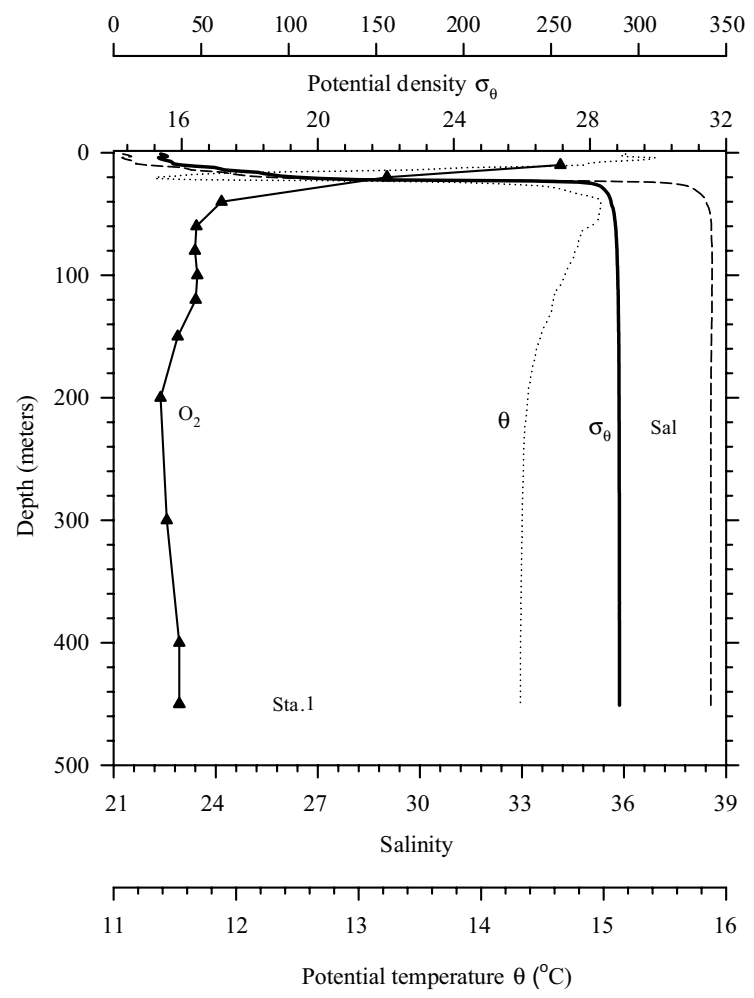

(b) $\quad \begin{array}{rllllllll}0.5 & 1.0 & 1.5 & 2.0 & 2.5 & 3.0 & 3.5 & 4.0 & 4.5\end{array}$

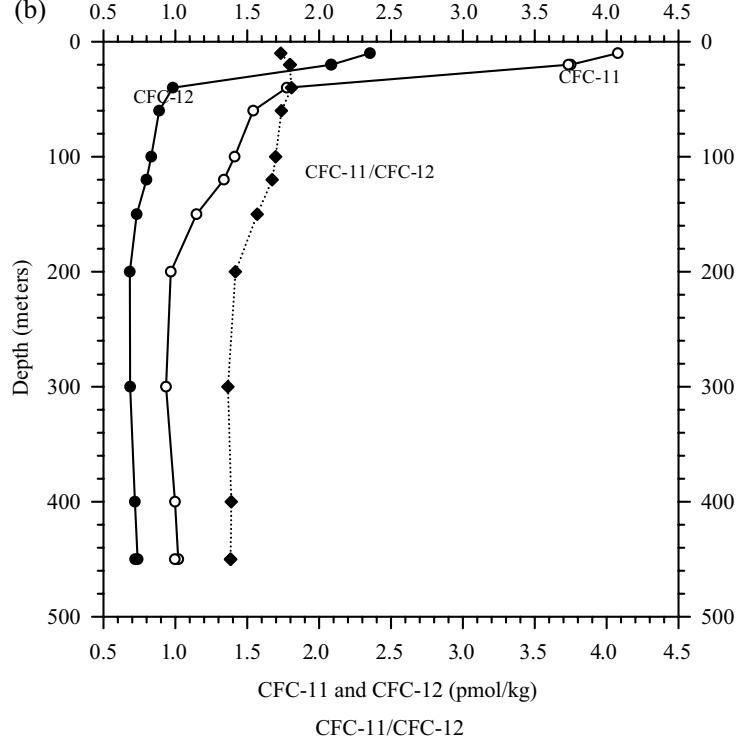

Fig. 7. Vertical profiles of $\theta, \sigma_{\theta}$, dissolved $\mathrm{O}_{2}$ and salinity (a) and vertical profiles of dissolved CFC-11 and CFC-12 concentration (b) at station $1\left(40^{\circ} 46^{\prime} \mathrm{N} 29^{\circ} 04^{\prime} \mathrm{E}\right)$ in the Sea of Marmara. Also shown is the $\mathrm{CFC}-11 / \mathrm{CFC}-12$ ratio for samples where CFC-11 and CFC-12 concentrations were both $>0.05 \mathrm{pmol} \mathrm{kg}^{-1}$.

CFCs in this layer. Here we adopt the Murray et al. (1991) CIL definition as waters colder than $8^{\circ} \mathrm{C}$, which corresponds to potential densities in the range 14.29-15.45. The CIL water is assumed to be in contact with the atmosphere in winter at the outcrop areas and isolated from the atmosphere during the rest of the year (Tolmazin, 1985; Ovchinnikov and Popov, 1987; Sanchez et al., 1991). Dissolved CFCs in outcropping CIL water are assumed to reach equilibrium with the atmosphere through air-sea exchange at the surface. Negligible dilution of CIL water with the lower CFC water from below this layer is also assumed.

The observed CFC-12 saturation ratio in the core of CIL water in 1988 was $73.8 \pm 13.2 \%$ (Fig. 8). The CFC-12 mixing ratio in the atmosphere increased at a rate of $\sim 5 \% \mathrm{yr}^{-1}$ for the 10 yr period prior to the 1988 expedition (see Fig. 2). If the dissolved CFC-12 concentration in CIL is assumed to track the atmosphere, then the observed CFC-12 saturation in CIL in 1988 reflects equilibrium with the atmosphere about $5 \mathrm{yr}$ earlier (1983). This $\sim 5 \mathrm{yr}$ timescale for CIL ventilation based on CFC-12 saturation levels is somewhat longer than the $1 \mathrm{yr}$ estimate of Tolmazin (1985), based on studies of temporal and spatial variations of the cold water transport in the CIL. However, there are two distinct groups of CFC saturation levels (Fig. 8) that reflect the strong vertical CFC gradient in the CIL (Fig. 6b). The $\sim 90 \%$ saturation level in the upper CIL waters is consistent with a $\sim 2$ yr turnover timescale. Also, if newly formed CIL waters do not attain full equilibration with respect to atmospheric CFC levels, then our estimates would be an upper limit for the ventilation timescale of CIL.

\subsection{Suboxic and anoxic CFC-bearing waters}

The relative vertical distributions of CFCs in the Black Sea indicate qualitatively that CFC-11 is not 


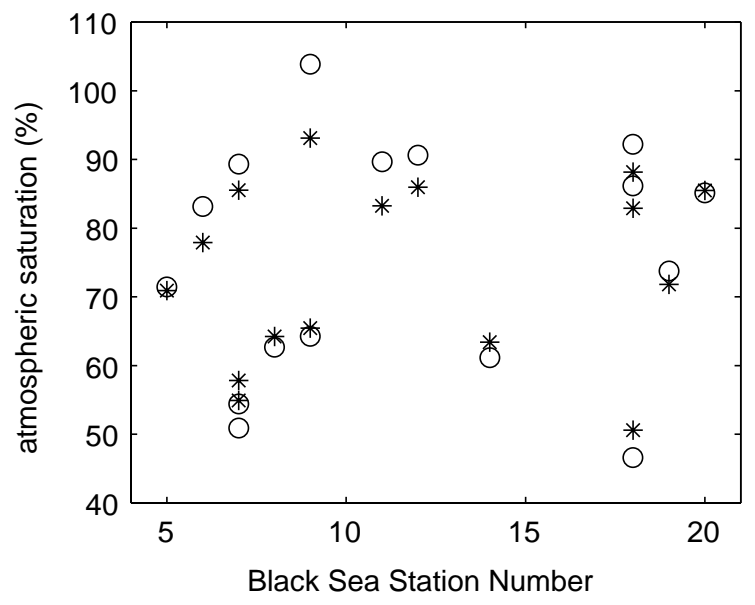

Fig. 8. CFC-12 (*) and CFC-11 (O) saturation levels with respect to the atmosphere measured in the Black Sea CIL samples whose temperature was $<8^{\circ} \mathrm{C}\left(15.45>\sigma_{\theta}>14.29\right)$.

conservative relative to $\mathrm{CFC}-12$ in suboxic and anoxic waters. This phenomenon has been reported in several anoxic basins, including Saanich Inlet, Canada (Bullister and Lee, 1995; Lee et al., 1999), Lake Nitinat, Canada (Lee, 1998) and Framvaren Fjord, Norway (Shapiro et al., 1997). CFC-12 appears to be essentially conservative in the anoxic waters in these basins, with modeled first-order removal rates from 0.01 to $0.03 \mathrm{yr}^{-1}$ (Shapiro et al., 1997), which may be indistinguishable from 0 , considering measurement and modeling errors. Assuming that $\mathrm{CFC}-12$ is conservative in oxygenated, suboxic and anoxic waters of the Black Sea, quantitative estimates of the removal rate of CFC-11, and estimates of the ventilation timescales of CIL, suboxic and anoxic deep waters can be estimated using a ventilation model tuned to $\mathrm{CFC}-12$.

A multi-layer horizontal box (HB) model (Fig. 9) was constructed to model the ventilation of the Black Sea deep waters below the CIL. The HB model consists of several reservoirs: Bosporus inflow (BI), CIL, 10 interface (IF) boxes (IF1IF10) and 11 horizontal boxes of $40 \mathrm{~m}$ thickness (zone 1-zone 11) below the CIL. Water in each IF box originates from instantaneous mixing of varying proportions of CIL and BI. The water in each IF box is laterally injected into each corresponding adjacent zone box of equal density.

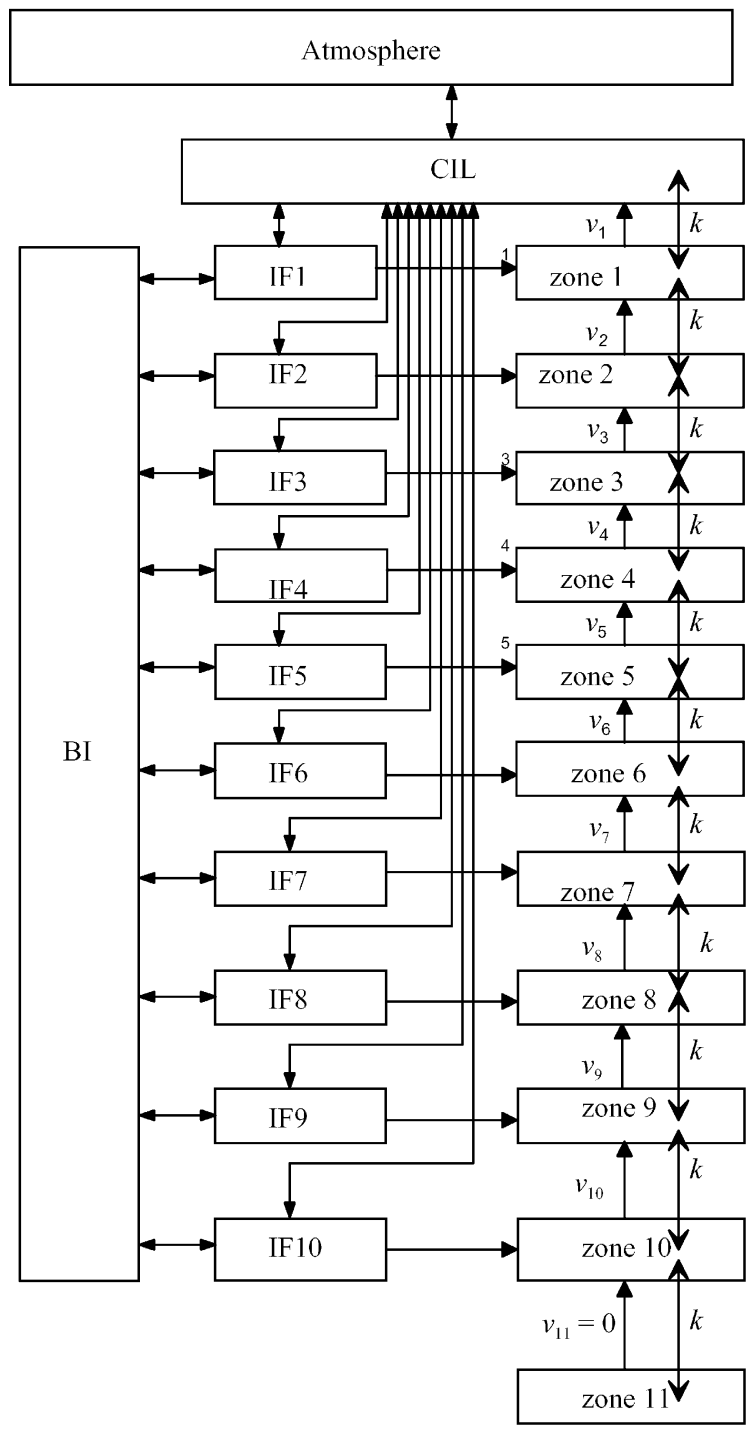

Fig. 9. Schematic diagram of the CFC multi-layer horizontal box model of the Black Sea.

The tracer properties in the zone boxes are governed by injection of water from the IF boxes and by vertical diffusion and upwelling. The distribution of tracers in each zone box was calculated as follows

$$
\begin{aligned}
\frac{\mathrm{d} C_{i}}{\mathrm{~d} t}= & \mu_{i} C_{i}^{\mathrm{IF}}-v_{i} C_{i}+v_{i+1} C_{i+1} \\
& +K\left(C_{i+1}-2 C_{i}+C_{i-1}\right)-k_{\mathrm{CFC}-11} C_{i} .
\end{aligned}
$$


In this equation, $\mu$ and $v$ are the lateral and vertical injection coefficients, respectively, $K=k / h^{2}$ ( $k$ is the depth-independent vertical eddy diffusivity and $h$ is the thickness $(40 \mathrm{~m})$ of the corresponding layer) and $k_{\mathrm{CFC}-11}$ is a layer dependent first-order in situ removal coefficient (applied only for CFC11). Lateral injection of water from each IF box renews the adjacent zone box and results in vertical transport (upwelling) of water to the overlying zone box. Thus, the water in the 10 upper zone boxes are renewed both by lateral injection from the adjacent IF box and by upwelling from the underlying zone box. The water in zone box 10 is renewed only by the lateral injection of water from the adjacent IF box. Vertical injection into zone box 10 from the deep water could not be constrained using CFCs because CFC-12 in water below $\sim 500 \mathrm{~m}$ was close to the blank level of $\sim 0.01 \mathrm{pmol} \mathrm{kg}^{-1}$. Here we assume no exchange with deeper $(>500 \mathrm{~m})$ waters.

The residence time of water in each zone box is equal to the volume in the reservoir of the zone box divided by the sum of the lateral and vertical volume inflow rates (Fig. 9). The lateral volume flux of water from each IF box equals the lateral injection coefficient, $\mu_{i}$, multiplied by the volume in the reservoir of the zone box $\left(V_{i}\right)$. The vertical volume flux of water from the $i$ th zone box is equivalent to the vertical volume flux coefficient $\left(v_{i}\right)$ multiplied by the volume in the reservoir of the $i$ th zone box $\left(V_{i}\right)$. The vertical volume flux of water from zone box 10 is $v_{10^{*}} V_{10}$ which is equivalent to the lateral volume flux, $\mu_{10^{*}} V_{10}$, therefore $v_{10}=$ $\mu_{10}$. For zone boxes $1-10$, the water mass budget in the modeled boxes is as follows

$v_{i}=\mu_{i}+v_{i+1}$.

To derive the history of a dissolved CFC in the CIL box (the CIL source function), the concentration of each dissolved CFC in CIL was assumed to track the atmospheric CFC source function (Fig. 2) at a constant saturation ratio. The saturation ratio used was $73.8 \%$ for $\mathrm{CFC}-12$ and $75.3 \%$ for CFC-11 in CIL determined from the dissolved CFC concentrations observed in the CIL during the 1988 cruise (Fig. 8), the atmospheric concentration measurements made in 1988, and the solubility of CFCs (Warner and Weiss, 1985) in CIL. Time series records from 1960-1988 indicate that the temperature and salinity in the core of CIL varies slightly with time (Konovalov and Murray, 2001). The range of these variations leads to only small changes in the calculated CFC solubility coefficients, and constant values for salinity of $18.90 \pm 0.41$ and $\theta$ of $7.06 \pm 0.24^{\circ} \mathrm{C}$ were used in calculating CFC solubility coefficients for CIL in the model.

No CFC samples were collected in the BI during the 1988 expedition. In 1992, CFC-113 and CFC11 measurements made in $\mathrm{BI}$ near the entrance of the Bosporus Strait yielded CFC-113/CFC-11 apparent ages for this water of about $6-11 \mathrm{yr}$ (Fogelquist et al., 1996). To derive a source function for dissolved CFCs in the BI box, the concentrations of dissolved CFCs in BI as a function of time were assumed to lag by $8.5 \pm 2.5 \mathrm{yr}$ the concentrations for CFCs in $\mathrm{BI}$ calculated at solubility equilibrium with the atmosphere. The solubility coefficients for CFC in BI used observations of salinity and potential temperature in Mediterranean origin water in the Bosporus, with mean salinity $=35$ and mean $\theta=14^{\circ} \mathrm{C}$ (Murray et al., 1991; Latif et al., 1991).

Potential density in each IF box was assumed to be in steady state and equivalent to that in the corresponding adjacent zone box. Salinity and potential temperature for each IF box were thus determined from the mixture ratio of CIL to BI which yielded the density equivalent to the corresponding zone box. The time-dependent source function of dissolved $\mathrm{CFC}$ for each IF box was calculated from the CIL and BI CFC source functions, and the mixing ratios of CIL to $\mathrm{BI}$ in each IF box. The mixing ratios of CIL to BI and the resulting concentrations of CFC in each IF box in 1988 are listed in Table 1. In tuning the model, mean $\pm 1 \sigma$ of the measured distributions of salinity and CFC concentrations for each zone box were used (Table 2).

In this model we assumed that circulation and hydrology were in steady state, so possible variations of Mediterranean inflow or river runoff to the Black Sea were not taken into account. Eq. (1) was integrated from 1930 to 1988 for CFC12, assuming zero initial concentrations in all boxes in 1930, using an explicit numerical method. 
Table 1

CFC-11 and CFC-12 concentrations ( $\mathrm{pmol} \mathrm{kg}^{-1}$ ), salinity, potential temperature $(\theta)$, and mixing ratio $(\gamma$, the ratio of CIL to BI water ) for each IF box, calculated as a two-endmember mixing between CIL and BI waters using potential density $\left(\sigma_{\theta}\right)$ as a mixing index

\begin{tabular}{rlllll}
\hline IF & $\gamma$ & CFC-12 & CFC-11 & Salinity & $\theta$ \\
\hline 1 & $9.95 \pm 4.67$ & $1.95 \pm 0.28$ & $4.49 \pm 0.86$ & $20.36 \pm 0.53$ & $7.91 \pm 0.47$ \\
2 & $5.73 \pm 1.21$ & $1.90 \pm 0.25$ & $4.36 \pm 0.77$ & $21.04 \pm 0.22$ & $8.20 \pm 0.33$ \\
3 & $4.93 \pm 0.78$ & $1.88 \pm 0.24$ & $4.30 \pm 0.74$ & $21.33 \pm 0.14$ & $8.32 \pm 0.29$ \\
4 & $4.55 \pm 0.62$ & $1.86 \pm 0.23$ & $4.30 \pm 0.72$ & $21.52 \pm 0.10$ & $8.40 \pm 0.27$ \\
5 & $4.32 \pm 0.53$ & $1.85 \pm 0.23$ & $4.25 \pm 0.71$ & $21.65 \pm 0.08$ & $8.45 \pm 0.26$ \\
6 & $4.10 \pm 0.52$ & $1.85 \pm 0.22$ & $4.23 \pm 0.71$ & $21.74 \pm 0.07$ & $8.49 \pm 0.25$ \\
7 & $4.03 \pm 0.44$ & $1.84 \pm 0.22$ & $4.22 \pm 0.70$ & $21.82 \pm 0.07$ & $8.53 \pm 0.25$ \\
8 & $3.91 \pm 0.41$ & $1.84 \pm 0.22$ & $4.20 \pm 0.70$ & $21.88 \pm 0.06$ & $8.55 \pm 0.25$ \\
9 & $3.84 \pm 0.40$ & $1.83 \pm 0.22$ & $4.20 \pm 0.69$ & $21.94 \pm 0.05$ & $8.58 \pm 0.24$ \\
10 & $3.78 \pm 0.37$ & $1.83 \pm 0.22$ & $4.19 \pm 0.69$ & $21.99 \pm 0.05$ & $8.60 \pm 0.24$ \\
\hline
\end{tabular}

Table 2

CFC-12 and CFC-11 concentrations ( $\mathrm{pmol} \mathrm{kg}^{-1}$ ), salinity and potential temperature $(\theta)$ (with uncertainty) calculated for each zone box

\begin{tabular}{|c|c|c|c|c|c|c|}
\hline Zone & $\sigma_{\theta}$ & & CFC-12 & CFC-11 & Salinity & $\theta$ \\
\hline 1 & 15.450 & -16.178 & $0.79 \pm 0.19$ & $1.22 \pm 0.54$ & $20.46 \pm 0.27$ & $8.18 \pm 0.22$ \\
\hline 2 & 16.178 & -16.451 & $0.47 \pm 0.07$ & $0.36 \pm 0.12$ & $21.02 \pm 0.09$ & $8.53 \pm 0.06$ \\
\hline 3 & 16.451 & -16.610 & $0.26 \pm 0.05$ & $0.13 \pm 0.08$ & $21.38 \pm 0.05$ & $8.69 \pm 0.02$ \\
\hline 4 & 16.610 & -16.717 & $0.15 \pm 0.03$ & $0.04 \pm 0.01$ & $21.57 \pm 0.07$ & $8.76 \pm 0.02$ \\
\hline 5 & 16.717 & -16.799 & $0.11 \pm 0.02$ & $0.03 \pm 0.01$ & $21.69 \pm 0.03$ & $8.79 \pm 0.01$ \\
\hline 6 & 16.799 & -16.858 & $0.07 \pm 0.01$ & $0.02 \pm 0.00$ & $21.81 \pm 0.02$ & $8.82 \pm 0.00$ \\
\hline 7 & 16.858 & -16.910 & $0.07 \pm 0.02$ & $0.03 \pm 0.03$ & $21.88 \pm 0.02$ & $8.83 \pm 0.00$ \\
\hline 8 & 16.910 & -16.950 & $0.04 \pm 0.00$ & $0.01 \pm 0.00$ & $21.95 \pm 0.00$ & $8.83 \pm 0.00$ \\
\hline 9 & 16.950 & -16.986 & $0.04 \pm 0.01$ & $0.01 \pm 0.01$ & $21.99 \pm 0.01$ & $8.84 \pm 0.00$ \\
\hline 10 & 16.986 & -17.016 & $0.02 \pm 0.01$ & $0.01 \pm 0.01$ & $22.03 \pm 0.01$ & $8.84 \pm 0.00$ \\
\hline
\end{tabular}

The 1988 Black Sea expedition stations used are 3, 5-9, 11, 12, 14, and 18-20.

The values for each $\mu_{I}$ and $v_{i}$ in the corresponding zone box and $K$ were determined by successive approximation to match the 1988 measured concentration of CFC-12 and salinity in each zone box simultaneously (Fig. 10).

Potential temperature predicted from the HB model is relatively lower than the observed potential temperature by up to $0.5^{\circ} \mathrm{C}$. Time-series observations of salinity and temperature at $\sigma_{\theta}=$ 14.5 for CIL water from 1960 to 1995 (Konovalov and Murray, 2001) showed that during 1960-1984 and in 1988, salinity decreased from 18.63 to 18.57 to $\sim 18.53$ and temperature decreased from $7.1-$ $7.6^{\circ} \mathrm{C}$ to $\sim 6.8^{\circ} \mathrm{C}$. The use of the low potential temperature observed for CIL in 1988 leads to low predictions of potential temperature in the deep waters in the HB model. Because of the observed variability of temperature in CIL water on decadal time scales, substantial errors arise in the temperature field in the HB model due to its steady-state assumption.

Variations of potential temperature and salinity in CIL water from the long term (1960-1988) background were about $0.7^{\circ} \mathrm{C}$ and $0.1^{\circ} \mathrm{C}$, respectively (Konovalov and Murray, 2001). Changes in the solubility coefficient of CFC-12 in the CIL water due to variations of temperature $\left(0.7^{\circ} \mathrm{C}\right)$ and salinity $(0.1)$ were $<4 \%$. The effects of variation in the salinity and temperature of CIL on the CFC12 distribution in each zone can be estimated, assuming the injection rate of surface-origin water into deep water was constant. The variation in the 

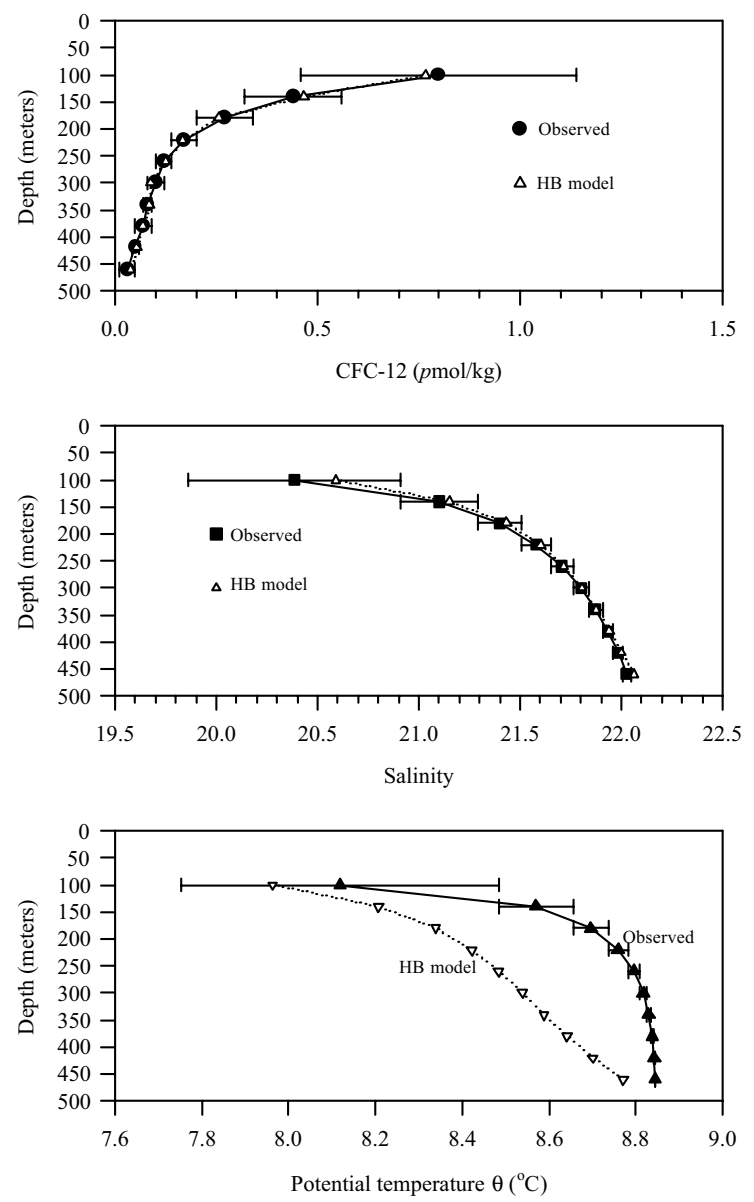

Fig. 10. HB model-derived CFC-12, salinity and potential temperature and the observed CFC-12, salinity and potential temperature in the Black Sea.

inventory of CFC-12 in each zone box due to solubility effects was $<\sim 0.2 \%$.

The model transport parameters cannot be uniquely determined from CFC-12 and salinity distributions because there are uncertainties in each zone box concentration. For many different values of vertical diffusivity within certain bounds, a set of model $\mu$ terms can be found that fits the salinity and CFC-12 distribution. Our model does place limits, however, on the range of vertical diffusivity values that are consistent with both the CFC and salinity distributions. The 1988 CFC-12 distribution indicates that a vertical diffusivity $>5 \times 10^{-6} \mathrm{~m}^{2} \mathrm{~s}^{-1}$ is not consistent with our model of the Black Sea's deep circulation. Diffusivities $>5 \times 10^{-6} \mathrm{~m}^{2} \mathrm{~s}^{-1}$ bring more CFC-12 into the suboxic and anoxic zone than was observed during 1988.

We used a Monte-Carlo approach to determine the water transport and mixing rates that best describe the 1988 CFC-12 and salinity distributions. CFC values for each zone box during 1988 were calculated from the mean $\pm 1 \sigma$ of the measured distribution. Similarly, for each year a CFC concentration in the BI and CIL were randomly selected from the mean $\pm 1 \sigma$ saturation levels observed in 1988, and the mean $\pm 1 \sigma$ of the temperature and salinity within the $\mathrm{BI}$ and CIL using the Walker et al. (2000) CFC atmospheric history and Warner and Weiss (1985) solubility. For each calculated CFC data set, transports $(\mu 1-\mu 10)$ were determined that fit the CFC data within $\pm 2 \%$, and this procedure was repeated 1000 times for several a priori designations of $k$, the model's vertical diffusivity.

For some CFC concentration scenarios no set of $\mu$ 's can be calculated that fits the 1988 calculated CFCs. These cases occur for two reasons: (1) When the calculated CFC in a zone box is higher than that in its adjacent interface box, the vertical diffusivity may not provide a large enough source of CFCs to that zone box. (2) Often, the calculated vertical supply (from above) of CFCs is too large to explain the very steep drop-off in CFC concentrations measured deeper than the CIL in 1988 (Fig. 6b). These latter cases become more probable with higher values of $k$.

The likelihood that a set of model $\mu$ 's can be found that fit the CFC observations generally decreased with increasing vertical diffusivity. The model can fit the CFC distribution $93 \%$ of the time for $k=0$. For higher diffusivities this probability decreases, as discussed above (Fig. 11). To determine the "best" model fit, we also evaluated the proportion of scenarios (that is, the likelihood) that the CFC-derived transports also explain the salinity distribution by a $\chi^{2}$ test. Unlike the situation for CFCs, the salinity distribution places a lower bound on likely values for $k$. This is because the mixing flux of salinity (density) necessarily dictates the upwelling rate through the zone boxes (Walin, 1982). The 


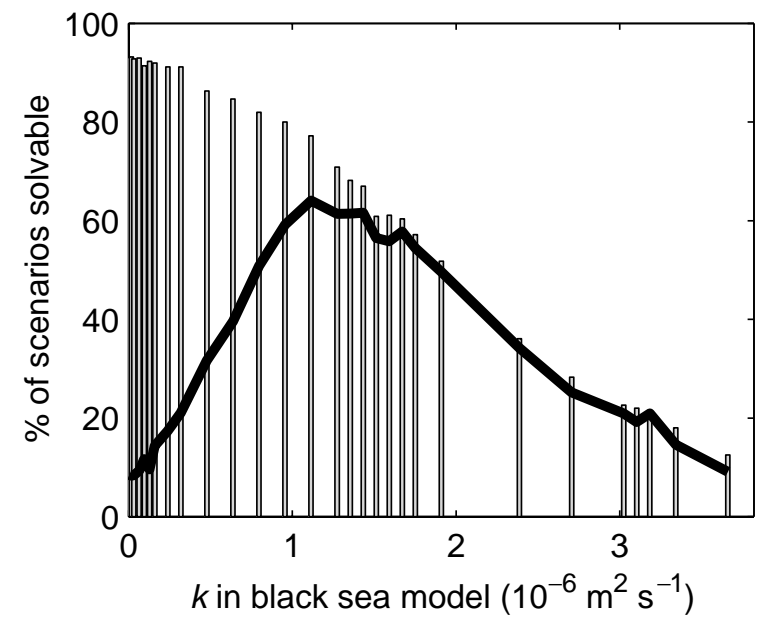

Fig. 11. Percentage of simulation scenarios where a valid transport was solved from among the Monte-Carlo simulations (bars), and the proportion of those solutions that also satisfied the concurrently measured salinity distribution by a reduced $\chi^{2}$ test (solid line).

maximum probability of satisfying both $\mathrm{CFC}$ and salinity constraints was found at $\sim 1.1 \times$ $10^{-6} \mathrm{~m}^{2} \mathrm{~s}^{-1}$. The minimum $k$ that provides solutions at $2 / 3(\sim 1 \sigma)$ of the maximum probability was about $0.6 \times 10^{-6} \mathrm{~m}^{2} \mathrm{~s}^{-1}$ and the maximum was about $2.2 \times 10^{-6} \mathrm{~m}^{2} \mathrm{~s}^{-1}$ (Fig. 11). Our model's circulation was thus constrained by both tracers, with CFC-12 furnishing an upper bound on $k$, and salinity providing a lower bound.

The best fit vertical diffusivity, derived from the CFC-12 HB model was $k=1.1( \pm 0.9) \times 10^{-6}$ $\mathrm{m}^{2} \mathrm{~s}^{-1}$. The magnitude of vertical diffusivity $k$ in the open oceans was reported to be in the range of $10-100 \times 10^{-6} \mathrm{~m}^{-2} \mathrm{~s}^{-1}$ (Munk, 1966; Matear and Wong, 1997) which is about one to two orders of magnitude higher than that calculated for the Black Sea deep waters. However, a similar value of $k$ was found in the strongly anoxic Fjord Framvaren with $k$ ranging from 0.1 to $2.7 \times 10^{-6} \mathrm{~m}^{2} \mathrm{~s}^{-1}$ (Tanhua, 1997). Microstructure measurements in the suboxic zone of the Black Sea (Gregg and Özsoy, 1999) for the suboxic-anoxic interface region also yielded estimates of vertical diffusion coefficients in the range of $10^{-6} \mathrm{~m}^{2} \mathrm{~s}^{-1}$. The extremely low $k$ in these two basins compared to the relatively high $k$ in the open ocean reflects the relatively strong stratification in these two basins and the lack of significant tides in the Black Sea, both of which likely contribute to the development of anoxic conditions. Gregg and Özsoy (1999) discuss the possibility that the existence of a suboxic zone in the Black Sea places an upper bound on $k$ of about $5 \times 10^{-6} \mathrm{~m}^{2} \mathrm{~s}^{-1}$ in this region.

The upwelling velocity for each zone box is equivalent to the zone thickness multiplied by the corresponding vertical volume flux coefficient and decreases with depth from 8 to $0.06 \mathrm{~m} \mathrm{yr}^{-1}$ in zones $1-10$, respectively (Table 3 ). The total upwelling in the system, that is, the uppermost upwelling flux, $v_{1}$, was $0.13 \mathrm{~Sv}$ in our best fit solution. This value is $50 \%$ higher than the value of $0.8 \mathrm{~Sv}$ that is obtained when the Bosporus inflow rate of $0.01 \mathrm{~Sv}$ (Unluata et al., 1989) is multiplied by the BI:CIL entrainment ratio of $1: 7.89$.

The model-derived residence time for the zone 1 (the suboxic zone) was $\sim 5 \mathrm{yr}$ and is not very different from the $\sim 8 \mathrm{yr}$ derived from the volume in the reservoir of the suboxic zone divided by the inflow rate derived from the entrainment of Bosporus inflow with CIL water. The volume of the suboxic zone is calculated based on the surface area of the Black Sea $\left(508,000 \mathrm{~km}^{2}\right)$ (Murray, 1991a), and the thickness of the suboxic zone

Table 3

Results of the HB model-derived upwelling velocity $w\left(\mathrm{~m} \mathrm{yr}^{-1}\right)$ and CFC-11 in situ removal coefficient $k_{\mathrm{CFC}-11}\left(\mathrm{yr}^{-1}\right)$ for each zone box

\begin{tabular}{cccl}
\hline Zone & Rt & $w$ & $k_{\text {CFC }-11}$ \\
\hline 1 & $4.8 \pm 3.6$ & $8.4 \pm 6.4$ & $0.15 \pm 0.13$ \\
2 & $12.5 \pm 5.9$ & $3.2 \pm 1.5$ & $0.24 \pm 0.06$ \\
3 & $21.1 \pm 8.9$ & $1.9 \pm 0.8$ & $0.66 \pm 0.10$ \\
4 & $30.8 \pm 9.5$ & $1.3 \pm 0.4$ & $0.70 \pm 0.18$ \\
5 & $44.4 \pm 15$ & $0.9 \pm 0.3$ & $0.55 \pm 0.11$ \\
6 & $59.7 \pm 22$ & $0.67 \pm 0.24$ & $0.47 \pm 0.10$ \\
7 & $85.1 \pm 31$ & $0.47 \pm 0.17$ & $0.48 \pm 0.13$ \\
8 & $129 \pm 54$ & $0.31 \pm 0.13$ & $0.55 \pm 0.16$ \\
9 & $235 \pm 110$ & $0.17 \pm 0.08$ & $0.57 \pm 0.18$ \\
10 & $625 \pm 430$ & $0.064 \pm 0.044$ & $0.31 \pm 0.21$ \\
\hline
\end{tabular}

The residence time $\mathrm{Rt}(\mathrm{yr})=1 / v\left(\mathrm{yr}^{-1}\right)$, the reciprocal of vertical volume flux coefficient for each corresponding zone box, and uncertainties reflect the relative uncertainties in $w$. 
(40 m). The inflow rate of $\sim 2500 \mathrm{~km}^{3} \mathrm{yr}^{-1}$ is based on a long-term estimate of BI of $312 \mathrm{~km}^{3} \mathrm{yr}^{-1}$ (Unluata et al., 1989) and an entrainment ratio of BI:CIL of 1:7.89 for the suboxic zone water. The residence time of water in each zone box (Table 3) increased with depth up to about $625 \mathrm{yr}$ in zone 10 $(\sim 500 \mathrm{~m})$. The residence times for depths below CIL and above the bottom $(2200 \mathrm{~m})$ have been estimated to be $\sim 387 \mathrm{yr}$ (Murray et al., 1991) and $850 \pm 300 \mathrm{yr}$ (Top et al., 1990). The residence time derived from the HB model for depths around $500 \mathrm{~m}$ range from 200 to $1000 \mathrm{yr}$ (Table 3). The uncertainty in this estimate is very large because the CFC-12 concentrations in the deepest layer were near the detection limit.

\subsection{CFC-11 removal rate coefficients}

The lateral and vertical injection coefficients and vertical diffusion coefficients determined using CFC-12 and salinity were used to estimate the first-order in situ removal coefficient $\left(k_{\mathrm{CFC}-11}\right)$ for CFC-11 in each depth layer. The calculations were carried out for CFC-11, assuming zero initial concentration of CFC-11 in all boxes in 1930. The value of $k_{\mathrm{CFC}-11}$ for each horizontal layer was determined by successive approximation to bring the model predicted CFC-11 concentration in each zone box to within $\sim 1 \%$ of the observed CFC- 11 concentrations in 1988 (Fig. 12).

The minimum calculated first-order in situ removal coefficient $k_{\mathrm{CFC}-11}$ is $0.15 \pm 0.13 \mathrm{yr}^{-1}$ in the suboxic zone (zone 1) at $\sim 80-120 \mathrm{~m}$ and the maximum value is $\sim 0.7 \pm 0.18 \mathrm{yr}^{-1}$ in zone 4 ( 200-240 m). The mean first-order CFC-11 in situ removal coefficient $k_{\mathrm{CFC}-11}$ was $\sim 0.47 \pm$ $0.05 \mathrm{yr}^{-1}$ in the depth range $160-480 \mathrm{~m}$ (Table 3). In the eastern tropical Pacific oxygen minimum zone, where the dissolved oxygen levels are in the same range as those in the Black Sea suboxic water, vertical profiles of $\mathrm{CFC}-11$ and $\mathrm{CFC}-12$ do not show any clear evidence for CFC-11 removal (Bullister and Lee, 1995). In this model, the small but non-zero CFC-11 removal term in the suboxic zone indicates the possibility of in situ CFC-11 removal, although the relative uncertainty in this number is substantial.

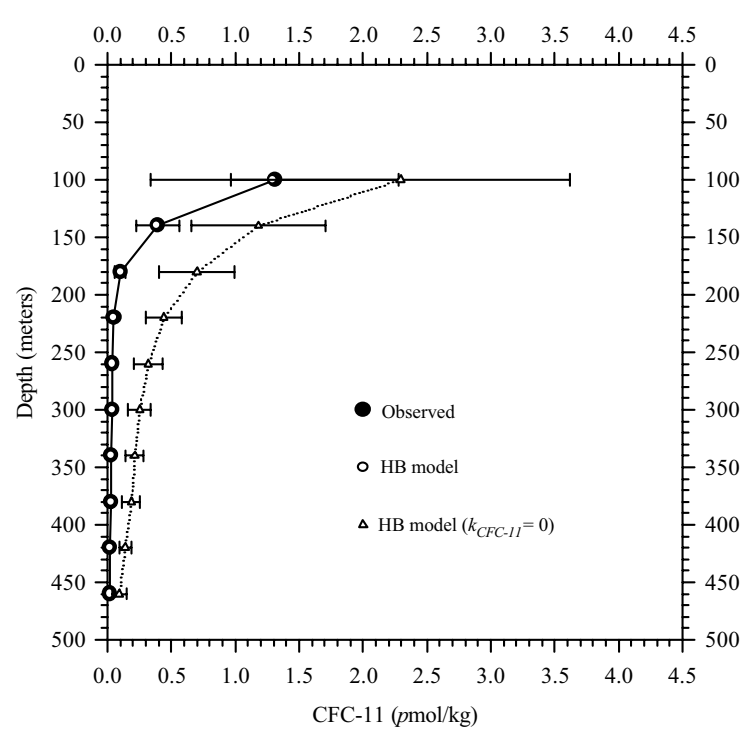

Fig. 12. Observed CFC-11 in the Black Sea, HB model-derived CFC-11 at best $k_{\mathrm{CFC}-11}$ for each zone layer and HB modelderived CFC-11 assuming $k_{\mathrm{CFC}-11}=0$.

CFC-11 removal rates have been estimated as 0.9 and $6-9 \mathrm{yr}^{-1}$, respectively, in two anoxic Basins: Saanich Inlet, BC, Canada (Bullister and Lee, 1995) and Framvaren Fjord, Norway (Shapiro et al., 1997). Long-term incubation experiments using anoxic hydrogen sulfide-bearing waters from Saanich Inlet yielded a CFC-11 firstorder removal coefficient $k_{\mathrm{CFC}-11}$ at $8^{\circ} \mathrm{C}$ of $0.5 \pm 0.3 \mathrm{yr}^{-1}$ (Lee et al., 1999). The first-order in situ removal coefficients for CFC-11 derived in this study and in Saanich Inlet are much lower than that from Framvaren Fjord. The differences in $k_{\mathrm{CFC}-11}$ values derived from these anoxic basins may be related to differences in chemical and/or biological activity in these regions and the contrast between the high primary production and particle fluxes in the coastal Framvaren site and the relatively oligotrophic Black Sea site.

\subsection{1-layer box model of CFCS in the Sea of Marmara}

A simple 1-layer box model incorporating CFC11 and $\mathrm{CFC}-12$ as conservative transient tracers was constructed to estimate the residence time and OUR of the Sea of Marmara deep water. The box 
model consisted of Dardanelles inflow (DI), the Sea of Marmara surface box, an IF box and a deep zone box with an upper boundary at $100 \mathrm{~m}$ and a bottom boundary at $450 \mathrm{~m}$ (Fig. 13). There were no CFC measurements in the water below $450 \mathrm{~m}$ on the 1988 expedition, so water below that depth was not included. In this model, the water in the deep zone box is renewed by new waters in the IF box which is a mixture of DI water and the Sea of Marmara surface water. The salinity, potential temperature and potential density of the IF water was assumed to be in steady state and equal to that observed in the deep zone box. CFC and dissolved oxygen levels in DI and the Sea of Marmara surface waters were assumed to be in equilibrium with the atmosphere. CFC and dissolved oxygen concentrations in water in the IF box, formed by mixing of DI and Sea of Marmara surface water, were assumed to be at equilibrium with the atmosphere at the temperature and salinity of the IF box water $\left(14.5 \pm 0.2^{\circ} \mathrm{C}\right.$ and $38.57 \pm 0.02$, respectively). Concentrations of dissolved CFC11, CFC-12 and oxygen at equilibrium with the overlying atmosphere in $1988(\mathrm{CFC}-11=268.5 \mathrm{ppt}$ and CFC-12=486.2ppt) in the IF box were $\sim 2.98 \pm 0.03,1.46 \pm 0.01 \mathrm{pmol} \mathrm{kg}^{-1}$ and $243.9 \pm$

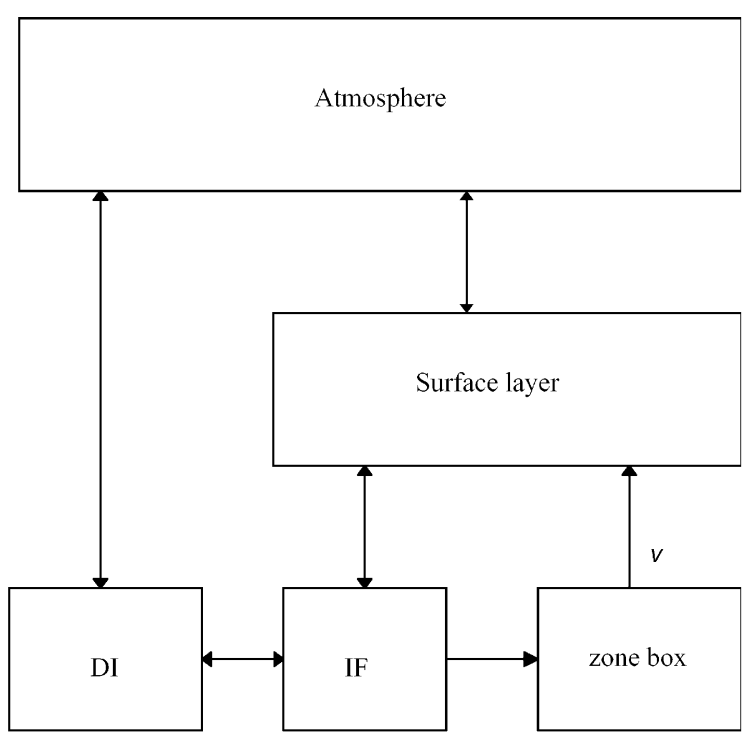

Fig. 13. Schematic diagram of the CFC box model for the Sea of Marmara.
$0.9 \mu \mathrm{mol} \mathrm{kg}{ }^{-1}$, respectively. Average measured concentrations of CFC-11, CFC-12 and dissolved oxygen in the deep water at station 1 in 1988 were $1.16 \pm 0.24, \quad 0.74 \pm 0.08 \mathrm{pmol} \mathrm{kg}^{-1}$ and $37.7 \pm 7.8 \mu \mathrm{mol} \mathrm{kg}{ }^{-1}$, respectively.

The CFC budget for the deep water of the Sea of Marmara was calculated using

$\frac{\mathrm{d}[C]_{\text {deep }}}{\mathrm{d} t}=\mu[C]_{\mathrm{IF}}-v[C]_{\text {deep }}$.

In this expression $\mu$ and $v$ are the lateral and vertical volume flux coefficients, respectively. In this case $\mu=v$ and the residence time of the deep water is $1 / v$. In this model the circulation was assumed to be in steady state. Eq. (3) was integrated numerically and the value for the vertical volume flux coefficient was determined by successive approximation to match the measured concentration of CFC in the deep water in 1988. The values of $\mu$ derived from CFC-11 and CFC- 12 were $0.046 \pm 0.015$ and $0.066 \pm 0.014 \mathrm{yr}^{-1}$, respectively. The respective residence times of deep water derived from $\mathrm{CFC}-11$ and $\mathrm{CFC}-12$ were $\sim 24 \pm 8$ and $16 \pm 3.5 \mathrm{yr}$. The relatively large difference in the values of $v$ derived using CFC11 and CFC-12 may be due in part to analytical problems (these were the first CFC samples measured on the expedition), errors in the reconstruction of atmospheric histories of CFCs prior to the availability of reliable direct measurements (errors are estimated as $\sim 2 \%$ in 1978 and increase to $>10 \%$ with increasing age (Doney and Bullister, 1992)) and most likely due to the simplifications inherent in this model. The residence time of the Sea of Marmara deep water below $100 \mathrm{~m}$ was computed as 6-7 yr using mass balance techniques (Unluata et al., 1989).

A rough estimate for the OUR in the deep water $\left(J_{\mathrm{O}_{2}}\right)$ can be obtained by assuming steady-state conditions and using the CFC derived flux coefficients from the simple Sea of Marmara model

$0=\mu\left[\mathrm{O}_{2}\right]_{\mathrm{IF}}-v\left[\mathrm{O}_{2}\right]_{\text {deep }}-J_{\mathrm{O}_{2}}$.

The OUR $\left(J_{\mathrm{O}_{2}}\right)$ of the Sea of Marmara deep water was thus calculated to be $9.8 \pm 3.7$ and $13.9 \pm 3.8 \mu \mathrm{mol} \mathrm{kg}^{-1} \mathrm{yr}^{-1}$, taking $\mu=0.046 \pm 0.015$ and $0.066 \pm 0.014 \mathrm{yr}^{-1}$, respectively. These rates 
are somewhat faster than those calculated from CFCs in the open North Atlantic (Doney and Bullister, 1992) but comparable to rates $\left(\sim 9 \mu \mathrm{mol} \mathrm{kg} \mathrm{kr}^{-1} \mathrm{yr}^{-1}\right)$ in the North Pacific derived using pCFC-11 apparent ages for water with residence time $<20 \mathrm{yr}$ (Warner et al., 1996).

\section{Conclusions}

A box-model tuned to CFC-12 was developed for estimating the residence times of suboxic water and deeper waters in the Black Sea. Estimated residence times of waters were about $\sim 5 \mathrm{yr}$ in the region of the suboxic layer and more than $500 \mathrm{yr}$ in the deep water. The model derived first-order CFC removal coefficient $k_{\mathrm{CFC}-11}$ was $\sim 0.15 \pm 0.13 \mathrm{yr}^{-1}$ in the suboxic zone and increased to $\sim 0.5 \pm$ $0.1 \mathrm{yr}^{-1}$ in the anoxic waters $(120-480 \mathrm{~m})$. The CFC-11 removal rates derived for Black Sea anoxic waters using the HB model are similar to that in Saanich Inlet but lower than estimates made for anoxic waters in Framvaren. This may reflect real differences in CFC-11 removal rates between oligotrophic regions and some productive coastal areas.

Estimates of residence times for deep water in the Sea of Marmara were 12-32 yr. The average of OUR in the deep water of the Sea of Marmara was $\sim 12 \mu \mathrm{mol} \mathrm{kg}^{-1} \mathrm{yr}^{-1}$ estimated by the CFC box model. The mean OUR in this region is comparable to the pCFC-11 apparent age derived mean OUR in other regions.

\section{Acknowledgements}

We thank Chief Scientists Zafer Top and Bob Anderson. Emin Özsoy provided much help with the CFC analyses. This paper was greatly improved by the efforts of Anatoly S. Samodurov and an anonymous reviewer. The hydrographic and sampling team supervised by George White provided the hydrographic data. This work was supported by NOAA's Office of Global Programs. This is National Center for Ocean Research, Taiwan, ROC contribution No. 5; NOAA-PMEL Contribution No. 1484; University of Washington
Contribution No. 1876; Joint Institute for the Study of Atmospheres and Oceans Contribution No. 521.

\section{References}

Besiktepe, S., Özsoy, E., Unluata, U., 1993. Filling of the Marmara Sea by the Dardanelles lower layer inflow. DeepSea Research I 40, 1815-1838.

Blatov, A.S., Kosarev, A.N., Tuzhilkin, V.S., 1980. Variability of the hydrographic structure of the Black Sea and its links with external factors. Vodnyye Resursy (Water Resources) 6, 71-82 (Russian).

Boguslavsky, S.G., Sarkisyan, A.S., Dzhioyev, T.Z., Kolesnikov, L.A., 1976. Analysis of the Black Sea current calculations. Atmospheric and Oceanic Physics 12 (3), 205-207 (English translation).

Buesseler, K.O., Livingston, H.D., Casso, S.A., 1991. Mixing between oxic and anoxic waters of the Black Sea as traced by Chernobyl cesium isotopes. Deep-Sea Research I 38 (Suppl.), S725-S745.

Bullister, J.L., Lee, B.S., 1995. Chlorofluorocarbon-11 removal in anoxic marine waters. Geophysical Research Letters 22, 1893-1896.

Bullister, J.L., Weiss, R.F., 1983. Anthropogenic chlorofluoromethanes in the Greenland and Norwegian Seas. Science 221, 265-268.

Bullister, J.L., Weiss, R.F., 1988. Determination of $\mathrm{CCl}_{3} \mathrm{~F}$ and $\mathrm{CCl}_{2} \mathrm{~F}_{2}$ in seawater and air. Deep-Sea Research I 35, 839853.

Caspers, H., 1957. Black Sea and Sea of Azov. In: Hedgpeth, J.W. (Ed.), Treatise on Marine Ecology and Paleocology, Geological Society of America Memoire, New York, NY, Vol. 67, No. 1, pp. 801-890.

Codispoti, L.A., Friederich, G.E., Murray, J.W., Sakamoto, C.M., 1991. Chemical variability in the Black Sea: implications of continuous vertical profiles that penetrated the oxic/ anoxic interface. Deep-Sea Research I 38 (Suppl.), S691S710.

Cunnold, D.M., Prinn, R.G., Fraser, P.J., Weiss, R.F., Simmonds, P.G., Miller, B.R., Alyea, F.N., Crawford, A.J., 1994. Global trends and annual releases of $\mathrm{CFCl}_{3}$ and $\mathrm{CF}_{2} \mathrm{Cl}_{2}$ estimates from $\mathrm{ALE} / \mathrm{GAGE}$ and other measurements from July 1978 to June 1991. Journal of Geophysical Research 99, 1107-1126.

Doney, S.C., Bullister, J.L., 1992. A chlorofluorocarbon section in the eastern North Atlantic. Deep-Sea Research I 39, 1857-1883.

Filippov, D.M., 1968. Circulation and Structure of Waters in the Black Sea. Nauka, Moscow, p. 136 (Russian).

Friederich, G.E., Codispoti, L.A., Sakamoto, C.M., 1990. Bottle and pumpcast data from the 1988 Black Sea Expedition. Technical Report, Monterey Bay Aquarium Research Center, pp. 90-93. 
Fogelqvist, E., Tanhua, T., Basturk, O., Salihoglu, I., 1996. The distribution of man-made and naturally produced halocarbons in a double layer flow strait system. Continental Shelf Research 16, 1185-1199.

Gammon, R.H., Cline, J., Wisegarver, D.P., 1982. Chlorofluoromethanes in the Northeast Pacific Ocean: measured vertical distribution and application as transient tracers of upper ocean mixing. Journal of Geophysical Research 87, 9441-9454.

Georgiev, Y.S., 1967. On dynamics of cold intermediate layer in the Black Sea. In: Okeanograpficheskiye issledovaniya Chernogo morya (Oceanographic investigations of the Black Sea). Naukova Dumka, Kiev, pp. 105-113.

Gregg, M.C., Özsoy, E., 1999. Mixing on the Black Sea shelf north of the Bosphorus. Geophysical Research Letters 26 (13), 1809-1872.

Ivanov, L.I., Besiktepe, S., Ozsoy, E., (1997). Black Sea cold intermediate layer. In: Özsoy, E., Mikaelyan, A. (Eds.), Sensitivity to Change: Black Sea and North Sea, Vol. 27, NATO ASI Series 2: Environment, Kluwer Academic Publishers, Dordrecht, pp. 253-264.

Khalil, M.A.K., Rasmussen, R.A., 1989. The potential of soils as a sink of chlorofluorocarbons and other man made chlorocarbons. Geophysical Research Letters 16, 679-682.

Khalil, M.A.K., Rasmussen, R.A., Wang, M.X., Ren, L., 1990. Emissions of trace gases from Chinese rice fields and biogas generators: $\mathrm{CH}_{4}, \mathrm{~N}_{2} \mathrm{O}, \mathrm{CO}, \mathrm{CO}_{2}$, chlorocarbons, and hydrocarbons. Chemosphere 20, 207.

Konovalov, S.K., Murray, J.W., 2001. Variations in the chemistry of the Black Sea on a scale of decades (1960-1995). Journal of Marine Systems 31 (1-3), 217-243.

Latif, M.A., Özsoy, E., Oguz, T., Unluata, U., 1991. Observations of the mediterranean inflow into the black sea. DeepSea Research I 38, S711-S723.

Lee, B.-S., 1998. Uses of Chlorofluorocarbons as ocean tracers and for estimating the removal rates of $\mathrm{CFC}-11$ and carbon tetrachloride in certain marine environments. $\mathrm{Ph}$.D. Thesis, University of Washington, Seattle.

Lee, B.-S., Bullister, J.L., Whitney, F.A, 1999. Chlorofluorocarbon CFC-11 and carbon tetrachloride removal in Saanich Inlet, an Intermittently Anoxic Basin. Marine Chemistry 66, 171-185.

Lovley, D.R., Woodward, J.C., 1992. Consumption of freons CFC-11 and CFC-12 by anaerobic sediments and soils. Environmental Science and Technology 26, 925-929.

Luther, G.W.III, Church, T.M., Powell, D., 1991. Sulfur speciation and possible sulfide oxidation in the water column of the Black Sea. Deep-Sea Research I 38 (Suppl.), S1121-S1137.

Matear, R.J., Wong, C.S., 1997. Estimation of vertical mixing in the upper ocean at Station P from chlorofluorocarbons. Journal of Marine Research 55, 507-521.

Munk, W., 1966. Abyssal recipes. Deep-Sea Research I 13, 707-730.

Murray, J.W., 1991a. The 1988 Black Sea oceanographic expedition: introduction and summary. Deep-Sea Research I 38 (Suppl.), S655-S661.
Murray, J.W., 1991b. Hydrographic variability in the Black Sea. In: Izdar, E., Murray, J.W. (Eds.), Black Sea Oceanography, Vol. 351, NATO ASI Series C: Mathematical and Physical Sciences. Kluwer Academic Publishers, Dordrecht, pp. 1-16.

Murray, J.W., Top, Z., Özsoy, E., 1991. Temperature and salinity distributions in the Black Sea. Deep-Sea Research I 38 (Suppl.), S663-S689.

Murray, J.W., Codispoti, L.A., Friederich, G.E., 1995. Redox environments: the suboxic zone in the black sea. In: Huang, C.P., O'Melia, C., Morgan, J.J. (Eds.), Aquatic Chemistry. American Chemical Society, Washington, D.C, pp. 157.

Neumann, G., 1943. Uber der Aufau und die Frage der Tiefenfenzirkulation des Schwarzen Meers. Alannalen Hydrographic and Maritimen Meterologic 7 (1), 1-20.

Östlund, H.G., Dyrssen, D., 1986. Renewal rates of the Black Sea deep water. In: Dyrssen, D., Walin, G. (Eds.), The Chemical and Physical Oceanography of the Black Sea. Reports of the Chemistry of the Sea XXXIII. University of Göteborg, Göteborg, Sweden.

Ovchinnikov, I.M., Popov, Y.I., 1987. Evolution of the cold intermediate layer in the Black Sea. Oceanography 27, $555-560$.

Özsoy, E., Unluata, U., Top, Z., 1993. The evolution of Mediterranean water in the Black Sea: interior mixing and material transport by double diffusive intrusions. Progress in Oceanography 31, 275-320.

Prinn, R.G., Weiss, R.F., Fraser, P.J., Simmonds, P.G., Cunnold, D.M., Alyea, F.N., O'Doherty, S., Salameh, P., Miller, B.R., Huang, J., Wang, R.H.J., Hartley, D.E., Harth, C., Steele, L.P., Sturrock, G., Midgley, P.M., McCulloch, A., 2000. A history of chemically and radiatively important gases in air deduced from ALE/GAGE/ AGAGE. Journal of Geophysical Research 105, 17751-17792.

Roemmich, D., 1983. Optimal estimation of hydrographic station data and derived fields. Journal of Physical Oceanography 13, 1544-1549.

Sabine, C., Key, R.M., Johnson, K.M., Millero, F.J., Poisson, A., Sarmiento, J.L., Wallace, D.W.R., Winn, C.D., 1999. Anthropogenic $\mathrm{CO}_{2}$ inventory of the Indian Ocean. Global Biogeochemical Cycles 13, 179-198.

Sanchez, A.L., Gustaud, J., Noshkin, V., Buesseler, K.O., 1991. Plutonium oxidation states in the southwestern Black Sea: evidence regarding the origin of the cold intermediate layer. Deep-Sea Research I 38 (Suppl.), S845-S853.

Shapiro, S.D., Schlosser, P., Smethie, W.M., Stute, M., 1997. The use of ${ }^{3} \mathrm{H}$ and tritiogenic ${ }^{3} \mathrm{He}$ to determine CFC degradation rates in Framvaren Fjord, Norway. Marine Chemistry 59, 141-157.

Tanhua, T., 1997. Halogenated substances as marine tracers. Ph.D. Thesis, Göteborg University, Sweden.

Tolmazin, D., 1985. Changing coastal oceanography of the Black Sea. I. Northwestern shelf. Progress in Oceanography $15,217-276$.

Top, Z., Izdar, E., Ergun, M., Konuk, T., 1990. Evidence of tectonism from $\mathrm{He}-3$ and residence time of helium in the 
Black Sea. EOS, Transactions of the American Geophysical Union 71, 1020-1021.

Unluata, U.T., Oguz, T., Latif, M.A., Özsoy, E., 1989. On the physical oceanography of the Turkish Straits. In: Pratt, L.J. (Ed.), The Physical Oceanography of Sea Straits, NATO ASI Series. Kluwer, Deventer, The Netherlands.

Walin, G., 1982. On the relation between sea-surface heat flow and thermal circulation in the ocean. Tellus 34, 187-195.

Walker, S.J., Weiss, R.F., Salameh, P., 2000. Reconstructed histories of the annual mean atmospheric mole fractions for the halocarbons CFC-11, CFC-12, CFC-13 and carbon tetrachloride. Journal of Geophysical Research 105 (C6), 14285-14296.

Warner, M.J., Weiss, R.F., 1985. Solubilities of chlorofluorocarbons 11 and 12 in water and seawater. Deep-Sea Research I 32, 1485-1497.
Warner, M.J., Bullister, J.L., Wisegarver, D.P., Gammon, R.H., Weiss, R.F., 1996. Basin-wide distributions of chlorofluorocarbons CFC-11 and CFC-12 in the North Pacific: 1985-1989. Journal of Geophysical Research 101, 20525-20542.

Weiss, R.F., Bullister, J.L, Gammon, R.H., Warner, M.J., 1985. Atmospheric chlorofluoromethanes in the deep equatorial Atlantic. Nature 314, 608-610.

White, G., Relander, M., Postal, J., Murray, J., 1989. Hydrographic data from the 1988 Black Sea oceanographic expedition. Special Report No. 109, Reference A89-1, University of Washington, School of Oceanography.

Woodruff, D., Diaz, H.F., Elms, J.D., Worley, S.J., 1998. Coads release 2 data and Metadata enhancements for improvements of marine surface flux fields. Physics and Chemistry of the Earth 23 (5-6), 517-526. 